Control of Hydrocarbon and Carbon Monoxide Emissions in the Tail Gases from Coal Gasification Facilities

\author{
J. F. Fisher \\ G. R. Peterson
}




\section{DISCLAIMER}

This report was prepared as an account of work sponsored by an agency of the United States Government. Neither the United States Government nor any agency Thereof, nor any of their employees, makes any warranty, express or implied, or assumes any legal liability or responsibility for the accuracy, completeness, or usefulness of any information, apparatus, product, or process disclosed, or represents that its use would not infringe privately owned rights. Reference herein to any specific commercial product, process, or service by trade name, trademark, manufacturer, or otherwise does not necessarily constitute or imply its endorsement, recommendation, or favoring by the United States Government or any agency thereof. The views and opinions of authors expressed herein do not necessarily state or reflect those of the United States Government or any agency thereof. 


\section{DISCLAIMER}

Portions of this document may be illegible in electronic image products. Images are produced from the best available original document. 
Printed in the United States of America. Available from National Technical Information Service

U.S. Department of Commerce

5285 Port Royal Road, Springfield, Virginia 22161

Price: Printed Copy $\$ 5.25$; Microfiche $\$ 3.00$

4.50

This report was prepared as an account of work sponsored by an agency of the United States Government. Neither the United States Government nor any agency thereof, nor any of their employees, contractors, subcontractors, or their employees, makes any warranty, express or implied, nor assumes any legal liability or responsibility for any third party's use or the results of such use of any information, apparatus, product or process disclosed in this report, nor represents that its use by such third party would not.infringe privately owned rights. 
Contract No. W-7405-eng-26

CHEMICAL TECHNOLOGY DIVISION

CONTROL OF HYDROCARBON AND CARBON MONOXIDE EMISSIONS IN THE

TAIL GASES FROM COAL GASIFICATION FACILITIES

J. F. Fisher

G. R. Peterson

Prepared for the

Division of Environmental Control Technology

Department of Energy

Date Published - August 1978

This report was prepared as an account of work sponsored by the United States Govermment. Neither the Energy, liur any of their employees, nor any of their contractors, subcontractors, or their employees, makes any warranty, express or implied, or assumes any lesal lisbility of responsibility for the accuracy, completeness or usefulness of any information, apparatus, prodect process diselosed or reprocont apartus, product or infringe privately owned rights.

OAK RIDGE NA'IIONAL LABORATORY

Oak Ridge, Tennessee 37830

operated by

UNION CARBIDE CORPORATION

for the

DEPARTMENT OF ENERGY 


\section{THIS PAGE}

\section{WAS INTENTIONALLY LEFT BLANK}


CONTENTS

$\underline{\text { Page }}$

ABSTRACT . . . . . . . . . . . . . . . . . . . . . . 1

1. INTRODUCTION . . . . . . . . . . . . . . . . . . I

2. SUMMARY OF RESULTS ..................... . . . 4

3. BASIS FOR THE STUDY . . . . . . . . . . . . . . . 7

3.1 Gas Flows and Compositions . . . . . . . . . . . 7

3.2 Emissions Standards ............... 9

4. PROCESS DESCRIPTIONS AND COST ESTIMATES .......... . 13

4.1 Basis and Accuracy of Cost Estimates . . . . . . . . 13

4.2 Detailed Process Descriptions ............. 15

4.2.1. Incineration in a coal-fired boiler . . . . . 15

4.2.2 Incineration in a boiler fired with

desulfurized medium-Btu gas ......... . 16

4.2.3 Catalytic incineration ........... . 19

4.2.4 Incineration - Aqua Claus process ....... . 21

4.2.5 Absorption (hot. carbonate process)....... 24

4.2.6 Absorption (cold water) ........... 26

4.2.7 Removal of $\mathrm{CO}$ by cuprous ammonium

carbonate solution............ . 27

4.2.8 Adsorption . . . . . . . . . . . . . . 30

4.2.9 Cryogenic separation

(liquefaction-d1st1llation) ........ . 32

4.2.10 Permeable membrane separation ........ 34

5. APPENDIX . . . . . . . . . . . . . . . . 37

6. ACKNOWLEDGMENTS . . . . . . . . . . . . . 38

7. REFERENCES ........................ . . . . . . . . . 


\title{
CONTROL OF HYDROCABON AND CARBON MONOXIDE EMISSIONS IN THE TAIL GASES FROM COAL GASIFICATION FACILITIES
}

J. F. Fisher

G. R. Peterson

\begin{abstract}
A study was made of the economics of various alternative methods of controlling emissions of $\mathrm{CO}$ and nonmethane hydrocarbons in the tall gases from a Lurgi substitute natural gas plant. Control of sulfur emissions was excluded from the scope of the study. Processes examined for decontaminating the tail gases included recovery and recycle methods as well as those that convert the contaminants to harmless products. The most recently proposed EPA emission standards for $\mathrm{CO}$ and nonmethane hydrocarbons were used as upper limfts for the residual contaminants in the treated effluent. Limited assessments of the technical and economic feasibility of ten processes were made. Of the processes studied, the two most promising were found to be incineration in a coal-fired boiler and catalytic incineration. Neither of these methods has been employed commercially under the projected operating conditions, although both are employed in other industries to carry out the basic reactions involved. Total capital and operating costs on a 20-year discounted cash-flow basis with $100 \%$ equity financing and $12 \%$ annual after-tax return on investment were estimated to be $4 c$ per $10^{6}$ Btu of SNG for the coal-fired boiler and $5 c$ per $10^{6}$ Btu for the catalytic case. However, the uncertainties in the costs were greater than the indicated cost differentials. The cost of incineration in a gas-fired boller using sulfur-free medium-Btu gas was estimated to be 1lc per $10^{6}$ Btu of SNG. All other routes examined were several times more expensive than these three methods.

As a result of the economic study presented, experimental studies on catalyst-alded incineration of typical tail gases will be initiated. Moreover, an industrial assessment of the impact and consequences of high tail-gas flow on the operating characteristics and design of a commercial boiler will be pursued.
\end{abstract}

\section{INTRODUCTION}

This report describes the results of a study of available and potentially available processes for the removal or destruction of $\mathrm{CO}$ and 
nonmethane hydrocarbons in the vent gases of Lurgi-type high-Btu coal gasification plants.* Thermal incineration of the vent gases has heretofore been the principal process considered for this application. 'The primary purpose of this study was to, determine whether there are environmentally acceptable alternatives to thermal incineration and, if so, whether they are economically attractive.

Examination of each alternative was based on its potential applicability in a Lurgi-type high-Btu gas plant using the Rectisol process* for acid-gas removal. The Lurgi process has been proposed for use in several large commercial plants for the pruduction of substitute natural gas (SNG) from coal in the western United Staces. SLandalds were pro. posed in $1976^{\circ}$ by EPA to regulate the emissions from such plantc.l The large-volume vent-gas (tail-gas) streams from the gas-treating portions of a Lurgi SNG facility are composed mainly of $\mathrm{CO}_{2}$ but may contain $0.2 \%$ (2000 ppmv) Co and $1 \%$ (10,000 ppmv) nonmethane hydrocarbons, as we11 as small amounts of sulfur compounds. The proposed E'HA standards would limit the concentrations of $\mathrm{CO}$ and nonmethane hydrocarbons to not more than $200 \mathrm{ppmv}$ and $100 \mathrm{ppmv}$, respectively. The same standards would also require that all sulfur emissions be in the form of $\mathrm{SO}_{\mathbf{x}}$ and would place upper limits on the concentration of $\mathrm{SO}_{\mathrm{x}}$ emitted. Thermal. incineration in the presence of air converts the co, hydrocarbons, and sulfur compounds to innocuous $\mathrm{CO}_{2}$, water vapor, and $\mathrm{SO}_{x}$, respectively. Incineration thus has the potential of meeting the proposed standards, provided the sulfur content of the tall gases and the fuel used in the incinerator is sufficiently low.

Many of the proposed gasification facilities use a coal-fired boller to generate the steam and electric power required by the various process units within the facllicy. Such a builer provides a convenient place. for disposing and incinerating the vent gases. However, it is not clear that this method of disposal would be in compliance with the $\mathrm{SO}_{2}$ limitations of the proposed EPA regulations, even if flue gas desulfurization were employed (see Appendix). It appears that the only feasible

\footnotetext{
${ }^{*}$ Trade name for Lurgi's low-temperature acid-gas absorption process.
} 
way of meeting the proposed regulations is to inclnerate the tall gases with a sulfur-free fuel; however, this procedure would be quite expensive because of the high cost of synthetic sulfur-free fuels. Based on these considerations, the objectives of the study were as follows:

1. To determine what processes are commercially available, or are in some stage of development, for the removal or destruction of co and nonmethane hydrocarbons in the vent gases of Lurgi coal gasiffcation plants using Rectisol acid-gas removal.

2. To assess the technical feasibility and cost of each process on the basis of the available commercial or experimental data.

Because the proposed EPA regulations have not yet been officially adopted, it was decided for purposes of this study to waive the requirement that all sulfur emissions be in the form of $\mathrm{SO}_{\mathrm{x}}$. This made it possible to consider a number of processes of potential interest other than incineration. When evaluating the results of the study, it should be kept in mind that most of the processes listed do not meet the proposed EPA sulfur standards and that incineration (either thermal or catalytic) is the only method presently available for ensuring that all sulfur emissions are in the form of $\mathrm{SO}_{\mathrm{x}}$. 


\section{SUMMARY OF RESULTS}

Ten available or potentially developable processes for the control of $\mathrm{CO}$ and hydrocarbon emissions were identified. These are 1isted in Table 2.1 along with their estimated overall capital and operating costs in cents per $10^{6} \mathrm{Btu}$ of product. The costs represent the additional product cost due to the type of treating process used; that is, they represent the added cost relative to hypothetical base case in which the tail gases are simply venced to the atuuspliere. Table 2.1 also gives a brief assessment of the technical feasibility of each process.

Incineration in a coal-fired boller, at a cost of $4 \varphi$ per $10^{6} \mathrm{Btu}$ of product gas, is the least expensive process. Catalytic incineration $\left(5 \mathrm{c} / 10^{6} \mathrm{Btu}\right)$ is its closest competitor; however, it is a much less proven process. Incineration with desulfurized synthesis gas (mediumBtu gas) costs $\sim 11 c / 10^{6} \mathrm{Btu}$; this is the base process used by EPA (by implication) in setting the proposed emissions standards. Both catalytic and direct incineration with the aid of desulfurized synthesis gas meet the tentative EPA criteria for SO $_{x}$ emissions. Incineration in a coalfired boiler meets both the letter and spirit of the law when low-sulfur western coals are fired, but may conflict with the law when high-sulfur coals are fired (see Append1x).

Al1 other processes identified in this study were several times more expensive than the three incineration methods. The treated gases from the other processes will contain a few ppmv of $\mathrm{H}_{2} \mathrm{~S}$ and $\mathrm{COS}$, which is in violation of EPA's tentative criterion that all sulfur be in the $\mathrm{SO}_{\mathrm{x}}$ form.

Costs were calculated by the discounted cash-flow procedure using the method described by R. Skamser of C. F. Braun $\&$ Co. ${ }^{2}$ Financing was assumed to be $100 \%$ equity with an annual after-tax rate of return of $12 \%$. Fuel costs were assumed to be $\$ 0.30 / 10^{6}$ Btu for coal and $\$ 3.50 / 10^{6} \mathrm{Btu}$ for treated SiNG. Other detalls of the cost calculations are yiven il Sect. 4. Costs are estimated to be accurate within a range of about $-25 \%$ to $+50 \%$ of the stated value. 
Table 2.1. Approximate cost of hydrocarbon and CO emissions control for Lurgi-type SNG plants $\alpha$

\begin{tabular}{|c|c|c|c|}
\hline $\begin{array}{l}\text { Process } \\
\text { no. }\end{array}$ & Description of processes & $\begin{array}{l}\text { Approximate cost } \\
\left(c / 10^{6} \mathrm{Btu} \text { SNG }\right)^{b}\end{array}$ & $\begin{array}{l}\text { Technical feasibility } \\
\text { for this application }\end{array}$ \\
\hline 1 & Incineration in a coal-fired boiler & 4 & Good \\
\hline 2 & $\begin{array}{l}\text { Incizeration in a boiler using lesulfurized } \\
\text { medium-Btu gas }\end{array}$ & 11 & Good \\
\hline 3 & Catalytic incineration & 5 & Unproved \\
\hline 4 & Aqua Claus process & $c$ & Unproved \\
\hline 5 & Hot carbonate scrubbing & 42 & Doubtful \\
\hline 6 & Cold water scrubbing & 56 & Doubtful \\
\hline 7 & Cuprous ammonium sclution absorption & 16 & Doubtfuld \\
\hline 8 & Adsorption & $c$ & $\begin{array}{l}\text { No practical } \\
\text { adsorbent known }\end{array}$ \\
\hline 9 & Cryog anic separation & 64 & $\begin{array}{l}\text { Technically } \\
\text { feasible }\end{array}$ \\
\hline 10 & Porous membrane separation & $c$ & Doubtful \\
\hline
\end{tabular}

$a_{\text {Most }}$ of the processes listed here have not been demonstrated in this type of application and cannot be considered. available for commercial use.

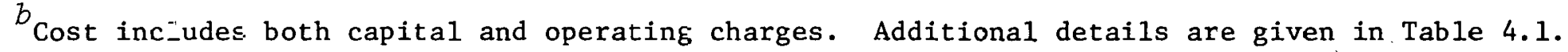

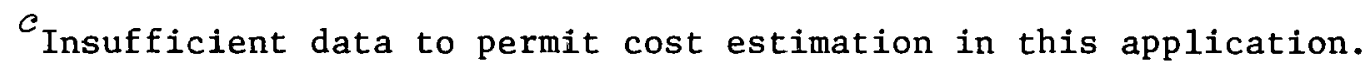

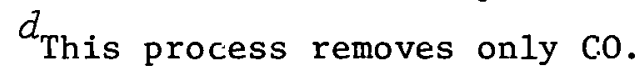


Technical feasibility has been fairly well established for the thermal incineration processes (processes 1 and 2), but not for the other processes. Catalytic incineration has been demonstrated in other applications, but its feasibility and catalyst life in this application are still undetermined. However, catalytic incineration is one of the few processes that is potentially capable of meeting the proposed EPA restrictions in regard to sulfur emissions.

Absorption and cryogenic processes have been well demonstrated in other applicatluins, but their usefulness in this application is questionable. The feasibility of adsorption and membrane diffusion processes is conjectural at thls lime.

In tho casp nf Lucineration in a coal- or gas-fired boiler, the large flows of inert vent gases could have an appreclable effect on the boiler operation, and the boiler would have to be designed to take such loads into account. 
3. BASIS FOR THE STUDY

\subsection{Gas Flows and Compositions}

Published Information on the WESCO plant, a typical proposed Lurgi SNG plant with an output of $250 \times 10^{6} \mathrm{scfd}$, was used as the basis for defining the flow rates and compositions of the various vent-gas streams. ${ }^{3-5}$ The WESCO plant will convert 19,540 tons of as-received low-sulfur western U.S. coal to SNG each day. The coal contains $0.8 \%$ sulfur, $21 \%$ ash, and $17 \%$ moisture and has a higher heating value of $8400 \mathrm{Btu} / \mathrm{lb}$. The boiler plant will burn an additional 4320 tons of coal per day. Daily by-product production will be 880 tons of tar $(0.5 \%$ sulfur), 440 tons of $\operatorname{tar}$ oil ( $0.25 \%$ sulfur), 200 tons of naphtha ( $0.2 \%$ sulfur), 130 tons of phenol, and 142 tons of sulfur.

Fig. 3.1 shows a schematic flowsheet of the relevant portions of the WESCO plant and gives approximate flow rates and compositions of the gas streams of interest. Raw synthesis gas (stream 1) is treated in a Rectisol unit to remove $\mathrm{H}_{2} \mathrm{~S}$. The sulfur-rich acid-gas stream from the Rectisol unit (stream 2) goes to an $\mathrm{H}_{2} \mathrm{~S}$ concentrator to increase the $\mathrm{H}_{2} \mathrm{~S}$ concentration to $270 \%$ and to reduce the hydrocarbon contaminants to a low level, thus permitting a more favorable mode of operation of the

Claus plant. The dilute acid-gas stream from the Rectisol unit (stream 4) contains $\sim 1 \% \mathrm{H}_{2} \mathrm{~S}$ and is treated in a Stretford plant. Tail gases from the Claus and the Stretford plants (streams 8 and 7 , respectively) are incinerated in the coal-fired boiler. A flue-gas desulfurization unit with a design removal efficiency of $90 \%$ provides $\mathrm{SO}_{2}$ removal from the boiler stack gases (see Appendix). The large low-sulfur tail-gas stream from the Rectisol plant (stream 3) is combined.with the tail gases from the SNG drying step (stream 11) and burned in an incinerator fired with low-sulfur fuel oil.

Streams used in this study for the purpose of analyzing alternative processes are the vent gases from the Rectisol and Stretford processes (streams 3 and 7 on the diagram). The Claus plant off-gas, stream 8 , is relatively small compared to the other two and hence was omitted for the sake of simplicity. It inclusion would have had no effect on the results of the study. 


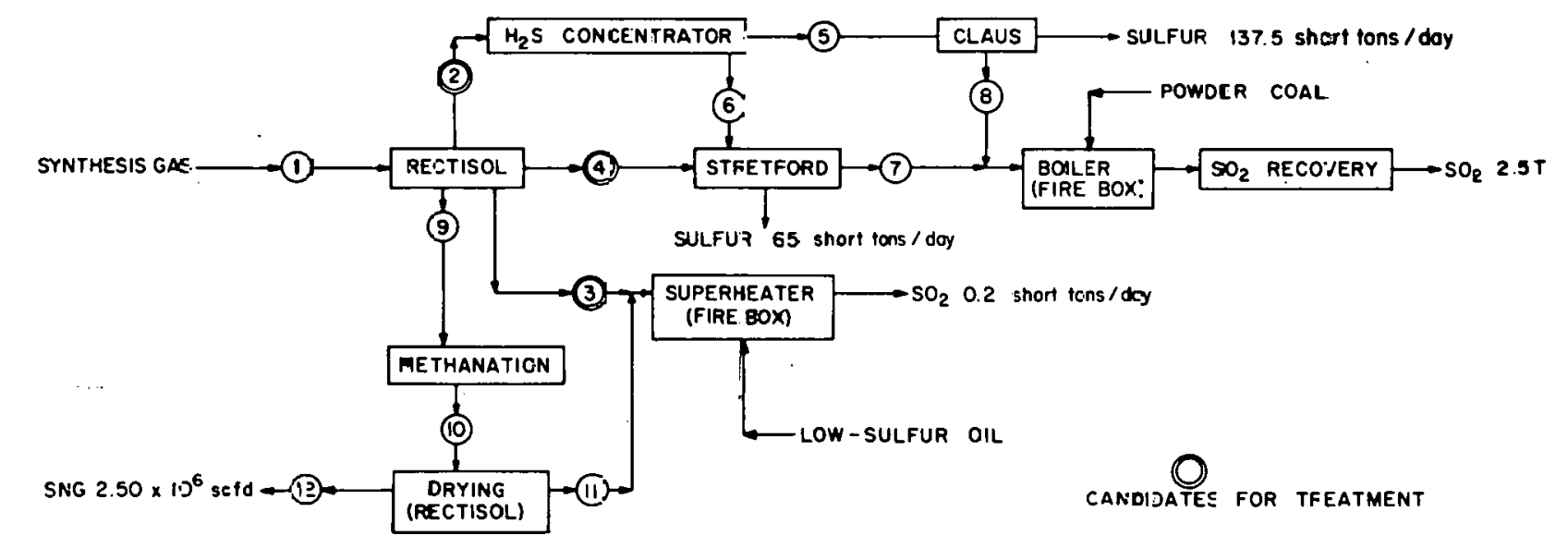

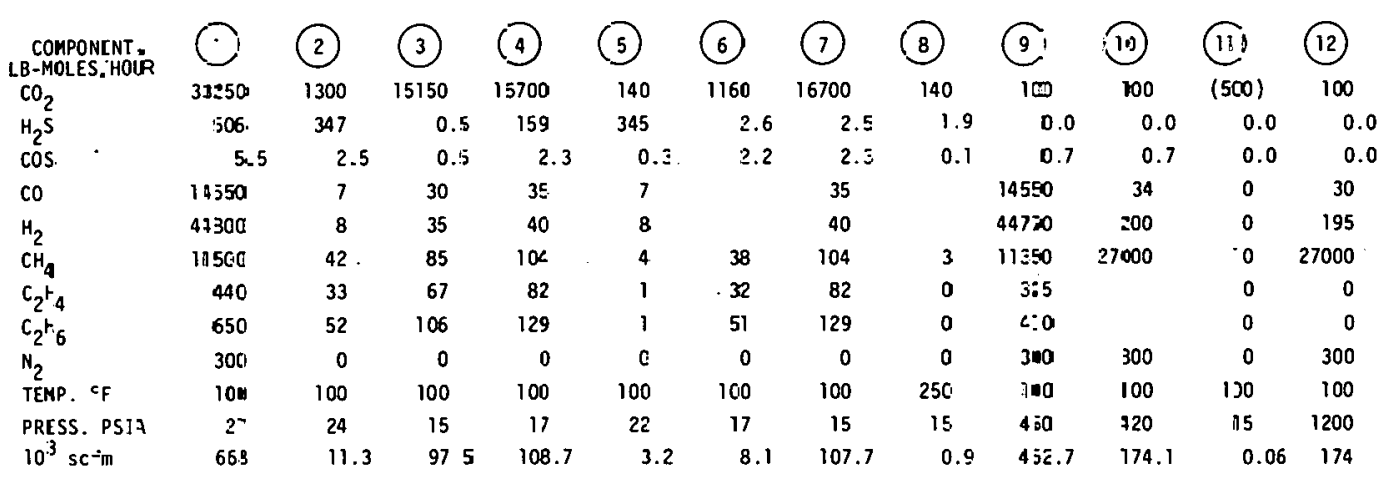

Fig. 3.1. WESCO-Lurgi acid-gas removal and hydrocarton control. 


\subsection{Emissions Standards}

EPA has proposed standards (November 1976) for allowable emissions of sulfur and hydrocarbons from Lurgi SNG plants. ${ }^{1}$ The standards are unusual in that they place limits on contaminants in specific tailgas streams from the gas-treating section of the plant rather than on the total emissions from the plant complex. With respect to the Rectisol plant tail gases, the proposed regulations require that all sulfur compounds be emitted as $\mathrm{SO}_{\mathrm{x}}$ and that the allowable. emission of nonmethane hydrocarbons be limited to 100 ppmv.

EPA limits are compared with the WESCO design in Table 3.1. Some of the individual streams in the WESCO design exceed the proposed EPA standards. However, if the EPA standards were applied on a total facility basis, the total sulfur emissions would be within the allowable limits.

New Mexico regulations limit $\mathrm{H}_{2} \mathrm{~S}$ emissions from gasification plants to $10 \mathrm{ppmv}$ and limit the sum of $\mathrm{H}_{2} \mathrm{~S}, \mathrm{COS}$, and $\mathrm{CS}_{2}$ emissions to $100 \mathrm{ppmv}$. Table 3.2 summarizes the WESCO plant emissions and the applicable New Mexico regulations. Emission standards for nonmethane hydrocarbons and Co are defined by their impact on the ambient air quality. Inder New Mexico regulations, it is feasible to use coal- or oil-fired boilers as incinerators. Allowable $\mathrm{SO}_{2}$ emissions from the boiler are calculated according to the following equation:

$$
W=E_{o} Q_{o}+E_{c} Q_{c}+E_{g} Q_{g}
$$

The variables used in this equation are defined as follows:

$$
\mathrm{W}=\text { total allowable } \mathrm{SO}_{2} \text { emission, } \mathrm{lb} / \mathrm{hr} \text {; }
$$

$\mathrm{E}_{\mathrm{o}}=$ allowable emission from oil, $1 \mathrm{~b} / 10^{6} \mathrm{Btu}$ of oil fired;

$Q_{0}=$ heat released by the oil based on the higher heating value, $10^{6} \mathrm{Btu} / \mathrm{hr}$;

$E_{c}=$ allowable emission from coal, $1 \mathrm{~b} / 10^{6} \mathrm{Btu}$ of coal fired;

$Q_{c}=$ heat released by the coal based on the higher heating value, $10^{6} \mathrm{Btu} / \mathrm{hr}$; 
Table 3.1. Comparison of various streams in WESCO SMG p-ant with profosed EPA emission standards ${ }^{a}$

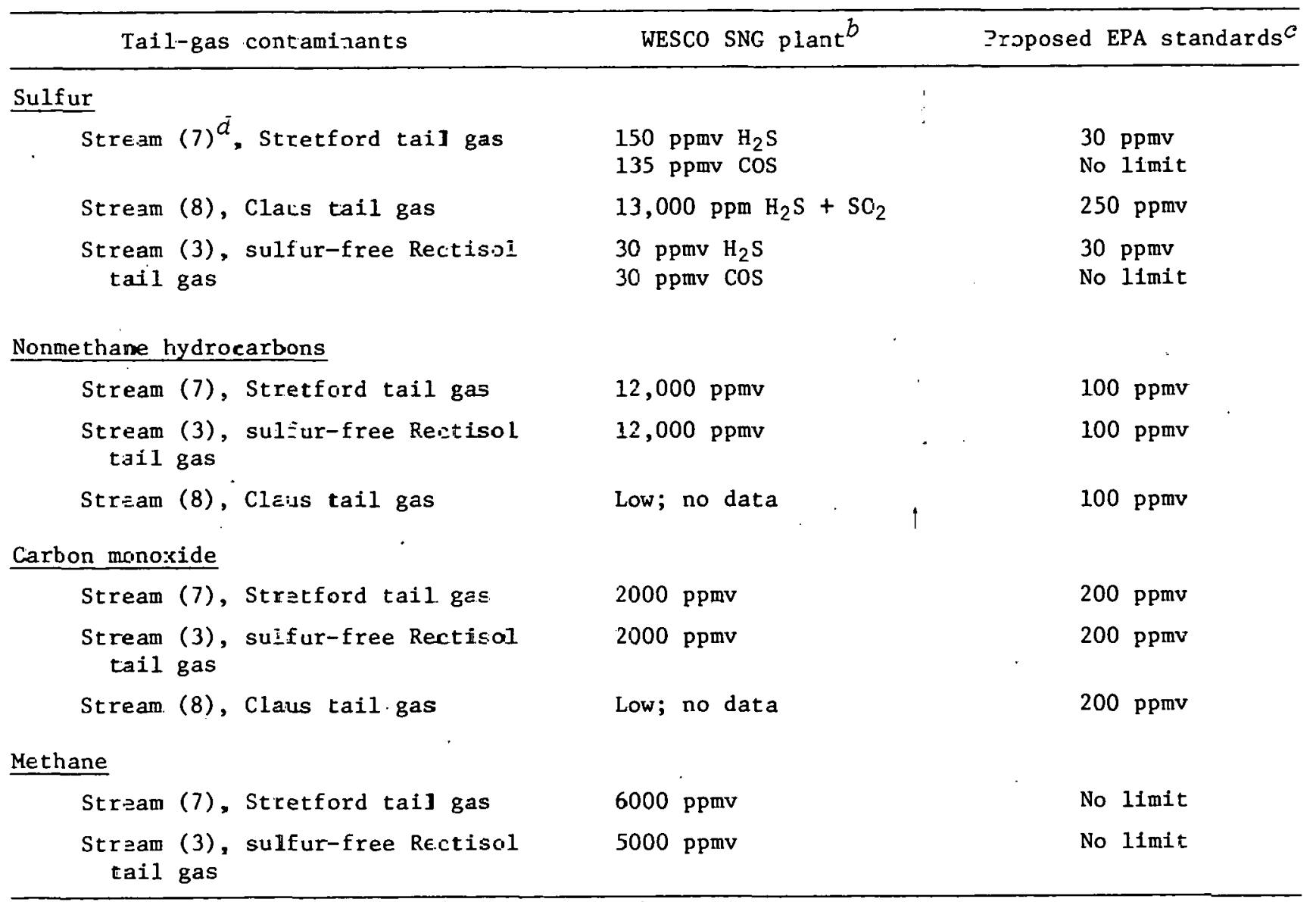

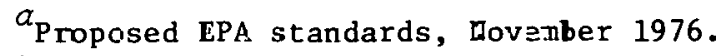

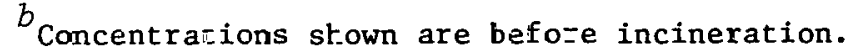

$c_{\text {Limits fo: }}$ sulfur compounds are given preincineration values, but incineration is required.

$d_{\text {Stream numbers }}$ refer to $\Xi i g .3 .1$. 
Table 3.2. Comperison of emissions from WESCO SNG plant with New Mexico emisston regulations

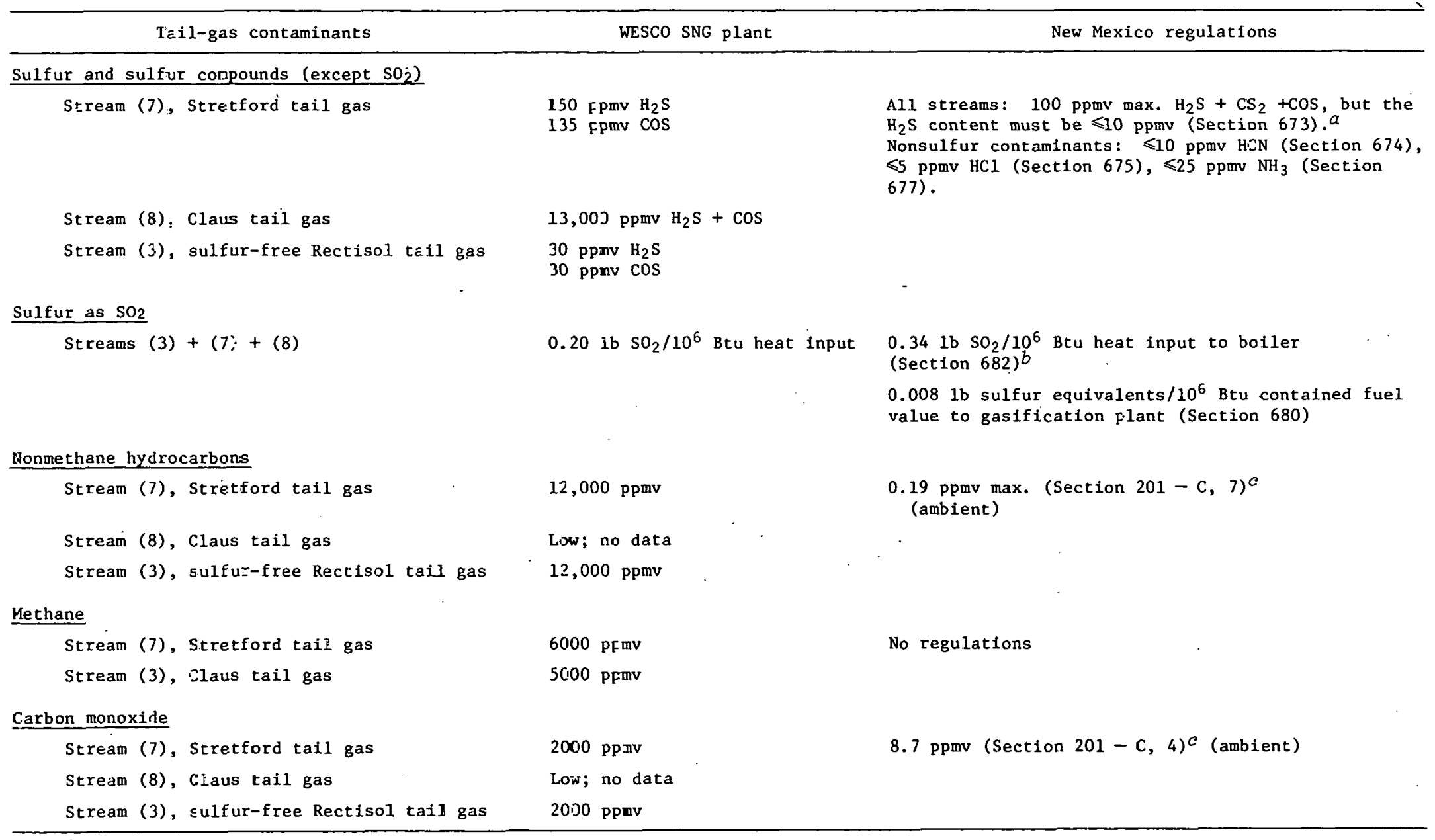

$a_{\text {Adopted Sept. } 14,1973 .}$

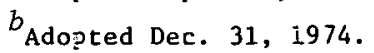

${ }^{c}$ Ambient air zuality standards adopted June 2, 1974. No compound-specific regulations covering $C_{2}+$ and co emissions from gasification plants. 
$\begin{aligned} E_{g}= & \text { allowable emission from gas, } 1 \mathrm{~b} / 10^{6} \mathrm{Btu} \text { of gas fired; and } \\ \mathrm{Q}_{\mathrm{g}}= & \text { heat released by the gas based on the lower heating value, } \\ & 10^{6} \mathrm{Btu} / \mathrm{hr} .\end{aligned}$

In using this equation, the allowable values $E_{o}, E_{c}$, and $E_{g}$ would be specified by the regulatory agency. 


\section{PROCESS DESCRIPTIONS AND. COST ESTIMATES \\ 4.1 Basis and Accuracy of Cost Estimates}

Table 4.1 summarizes the various processes and presents a breakdown of the estimated costs. As mentioned earlier, these costs represent the additional or incremental cost compared to a hypothetical base case in which the tail gases are simply released to the atmosphere. The cost of this $2.50 \times 10^{8}$-scfd Lurgi SNG plant is about $\$ 1.5$ billion. 6 The costs are broken down into: estimate incremental capital investment, capital charges, fuel cost, catalyst cost, other costs including power and labor, and a total yearly incremental capital and operating cost. Total yearly costs are also reported on a cents-per $-10^{6}$ Btu basis. As indicated in the table, the economics is based on a 20-year discounted cash-flow calculation using $100 \%$ equity financing and an annual aftertax rate of return of $12 \%$.

The cost estimates are rather approximate. Overall accuracy limits are estimated to be in the range of $-25 \%$ to $+50 \%$. In some cases, the plant costs were scaled from reported costs for generally similar systems. The clean fuel gas-fired incinerator cost was scaled from a gas-fired boiler cost developed for Coalcon. ${ }^{7}$. This estimate agreed with the value developed by the J. Zink Company. ${ }^{8}$ The incinerator is essentially a 20-MW boiler.

The same procedure could be followed only in part in the coalfired boller case. The plant capacity from the convection section through the stack gas cleanup was simply scaled up by $50 \%$. This corresponds to the increase in the gas flow rate through the boiler caused by the introduction of the tail-gas streams into the fire box. The cost was then scaled up using an exponent of 0.6 . Costs for modifying the radiant section of the furnace and the possible cost increases in coal grinding were not estimated. These could best be established tliruugh a detailed study by a qualified boller manufacturer or engineering firm specializing in such studies. The costs of the radiant section were arbitrarily increased in proportion to the flue-gas flow rate. It was assumed that there was no loss in combustion efficiency. scale-up was based on coal-fired boiler costs that were reported for coalcon. 7 
Téble 4.1. Increnental capital and operating costs for selected effluent treatment processes applied to a $2.50 \times 10^{8}$-scfó Lurgi SNG plant $a$

\begin{tabular}{|c|c|c|c|c|c|c|c|c|c|}
\hline \multirow[b]{2}{*}{$\begin{array}{l}\text { Process } \\
\text { no. }\end{array}$} & \multirow[b]{2}{*}{ Name } & \multirow{2}{*}{$\begin{array}{c}\text { Es:jmated } \\
\text { caEital } \\
\text { investment } \\
\left(\$ \vdots 0^{6}\right)\end{array}$} & \multicolumn{6}{|c|}{ Capital and operatirg costs $\left(\$ 10^{6} / \text { year }\right)^{b}$} & \multirow{2}{*}{$\begin{array}{c}\text { Total } \\
\operatorname{cost} \\
\left(c / 10^{6} \quad B t u\right)\end{array}$} \\
\hline & & & $\begin{array}{l}\text { Capital } \\
\text { charges }\end{array}$ & Fuel ${ }^{c}$ & Steam ${ }^{\prime}$ & Catalyst & Other & Total & \\
\hline 2 & $\begin{array}{l}\text { Incineration in medium-Btu, } \\
\text { gas-fired toiler }\end{array}$ & 6 & 1.5 & 12.0 & $(5.0)$ & & 1.5 & 10.0 & 11 \\
\hline 3 & Catalytic oxidation & 14 & 3.5 & 0 & $(1.8)$ & 0.3 & 2.6 & 4.6 & 5 \\
\hline 4 & Aqua Claus & & & & & & & & $f$ \\
\hline 5 & Hot carbonate scrubbing & 38 & 9.4 & $(8.0)$ & 19 & & 17.9 & 38.3 & 42 \\
\hline 6 & Cold water scrubbing & 66 & 16.3 & $(8.0)$ & 8 & & 23.4 & 39.7 & 44 \\
\hline 7 & Cuprous ammonium soletion abssorption & 20 & 4.9 & $(0.2)$ & 2 & & 7.9 & 14.6 & 16 \\
\hline 8 & Adsorption & & & & & & & & $f$ \\
\hline 9 & Cryogenic separation & 100 & 24.7 & $(8.0)$ & 13. & & 28.7 & 58.4 & 64 \\
\hline 10 & Porous membzane sepa:ati=n & 75 & 18.5 & 0 & 6 & & & & $f$ \\
\hline
\end{tabular}

Basis: 20-year jiscounted cash-flow method with $100 \%$ equity financing and $12 \%$ return or. equity after taxes.

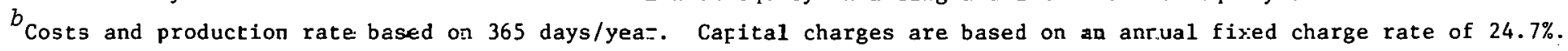
${ }^{c}$ Coal at $\$ 0.30 / 10^{\bar{E}}$ Btu; medium-Etu gas (synthesis gas) at $\$ 3.50 / 10^{6}$ Btu; recycled icontaninated) fuel gas credited at $\$ 3.00 / 10^{6}$. Product SNC was estimated at $\$ 4.00 / 10^{6} \mathrm{Et} \cdot \mathrm{s}$.

$d_{\text {Steam }}\left(900 \mathrm{psig}, 825^{\circ} \mathrm{F}\right)$ is escimated at $\left.\$ 1.35, i\right)^{3} 1 \mathrm{~b}$.

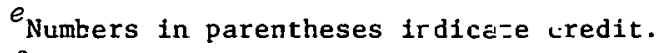

$f_{\text {Insufficient data to pernit cost estimation. }}$ 
The accuracy of estimates made for the hot carbonate acid-gas absorption system is approximately the same as that for the coal-fired boiler. The costs available were those of the standard, single-stage acid-gas removal process. The proposed two-stage process relies on the relative rates of absorption of $\mathrm{H}_{2} \mathrm{~S}$ and $\mathrm{CO}_{2}$ in the first stage for the selective removal of $\mathrm{H}_{2} \mathrm{~S}$ and on a partial $\mathrm{CO}_{2}$ flash after the second stage for removal of the dissolved hydrocarbons. In the absence of operating data for these alternatives, the sizes of additional process equipment could only be roughly estimated.

The costs of most of the other processes were based on approximate heat and material balances and shortcut methods of equipment sizing (based on mass or heat flows). This procedure was applied to the coldwater acid-gas absorption, cryogenic separation, and adsorption processes. The most uncertain cost in the analysis is that for membrane separations. General Electric's projection ${ }^{9}, 10$ for the manufacture of membranes on a commercial scale was employed without alteration. Membranes with surface areas of a few square feet have been prepared, but the application contemplated here would require surface areas of over 8 million square feet. Costs for the adsorption and membrane separation cases were developed only to give an indication as to whether such systems have sufficient potential to justify further development for this application.

Accuracy limits for the energy-related operating costs are believed to be in the range of $-20 \%$ to $+30 \%$.

\subsection{Detailed Process Descriptions}

In this section, the processes are discussed from the standpoint of their additional capital and operating requirements and equipment modifications in cumparisons with the hypothetical base case.

\subsubsection{Incineration in a coal-fired boiler}

The WESCO boiler flue-gas flow is $\sim 85,0001 \mathrm{~b}$-moles/hr before the tail gases are added. Incineration of the contaminated $\mathrm{CO}_{2}$ streams will increase this flow by 45,000 lb-moles/hr. A schematic flow diagram for 
this process is presented in Fig. 4.1. Incineration of the co requires temperatures of $\sim 1800^{\circ} \mathrm{F}$ in the radiant section of the boiler. The addition of the tail gases will drastically reduce the gas temperature in the radiant zone and will appreciably increase the emissivity of the flue gas. Before the tail gases enter the boiler, they should be preheated by exchange with the flue gas to avoid losses in the overall thermal efficiency and to avoid excessive cooling of the radiant zone. Reductions in the burning rate may be offset by grinding the coal feed to a finer consistency; however, the intensicy of the flame in the burner zone will incredse with a fincr coal feed. Rased on these constderalions, it is apparent that the boiler design and efficiency could be apprectably affected by the introduction of the tail gadeo into the fire bux.; Computer programs for boiler design could probably be used to evaluate the effect of tail-gas incineration on the overall efficiency and cost.11 As indicated in Table 4.1, the difference in capital cost for the coal-fired boiler case above the base case was estimated at $\$ 9$ million. The increased costs of the boiler, flue gas desulfurization unit, and electrostatic precipitator account for $\$ 5.3 \mathrm{million}, \$ 3.4 \mathrm{million}$, and $\$ 0.3$ million, respectively. These ruugh estinates werc mada by using scaling factors based on the increased throughput of flue gas.

The reduction of tuel ronsumptol was estimated at $\$ 0.2 \mathrm{millinn} / \mathrm{year}$. This was based on an estimated $2.6 \times 10^{9}$ Btu of heat input per hr to the boiler in the base case, of which $23 \%$ is consumed by the induceddraft fans and grinding mills and $\sim 3 \%$ to $4 \%$ is used by the flue gas wetscrubbing system.12,13 It was estimated that the increased energy roquirements would be $\sim 140$ million $\mathrm{Btu} / \mathrm{hr}$ and that the net recoverable energy from burning the $\mathrm{CO}$ and hydrocarbons would be $\sim 200 \mathrm{million} \mathrm{Btu} / \mathrm{hr}$. This leads to an overall net saving of $60 \mathrm{million} \mathrm{Btu} / \mathrm{hr}$, or abuul $\$ 0.2 \mathrm{million} / \mathrm{year}$.

\subsubsection{Incineration in a boller fired with desulfurized medium-Btu gas}

The flowsheet for this option is shown in Fig. 4.2. It was estimated that a temperature on the order of 1600 to $1800^{\circ} \mathrm{F}$ would be required for essentially complete combustion of the $\mathrm{CO}$ and hydrocarbons in the tail gases fed to the boiler. 8,14 If the gases entering the 
ORNL OWG 77-1713R

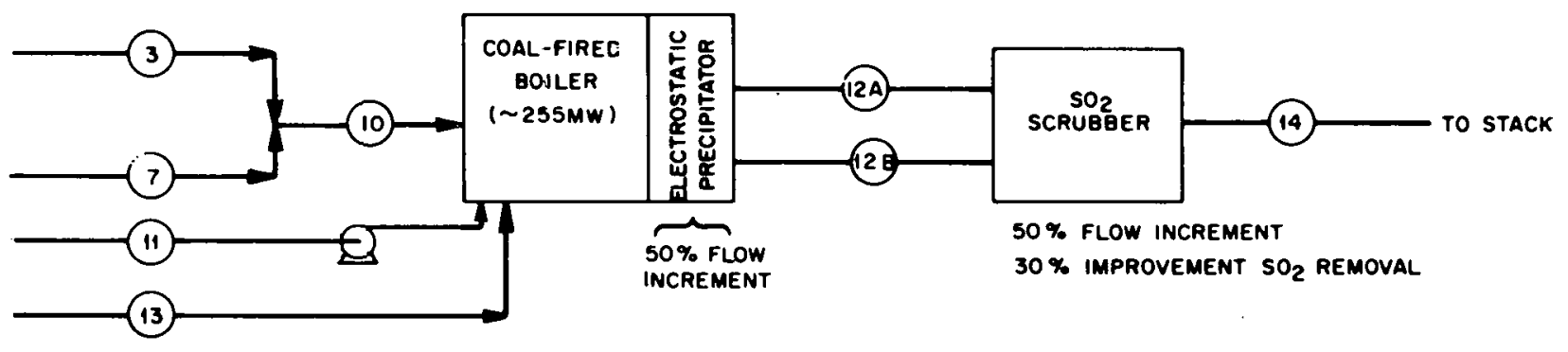

STREAMS (2A) AND (12B REFLECT THE CONTR IBUTIONS OF THE CONTAMINATED AND THE NORMAL

APPROXIMATE STREAM FLOWS FOR EQUIPMENT SIZING, LB-MOLES/HOUR:

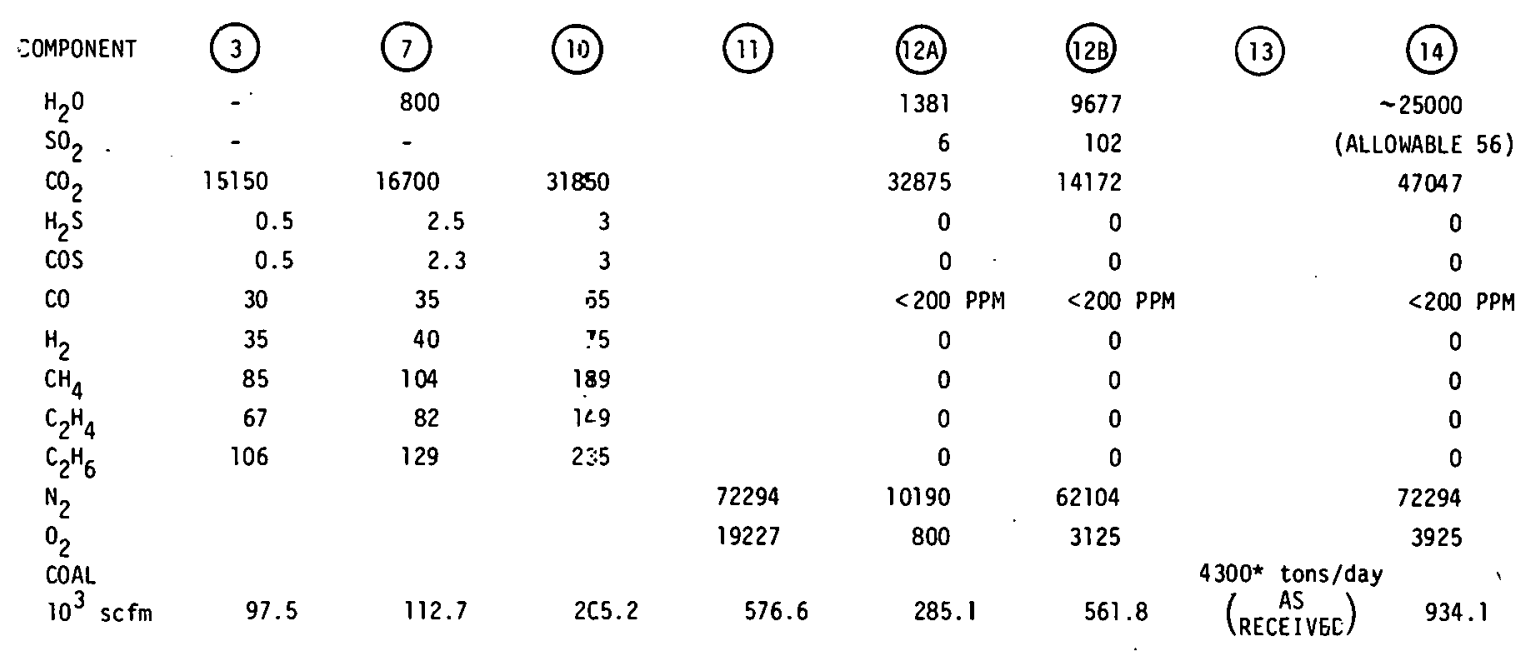

* NORMAL COAL FEED RA-E TO WESCO BOIIER

Fig. 4.1. Incireration in coal-fired boiler. 


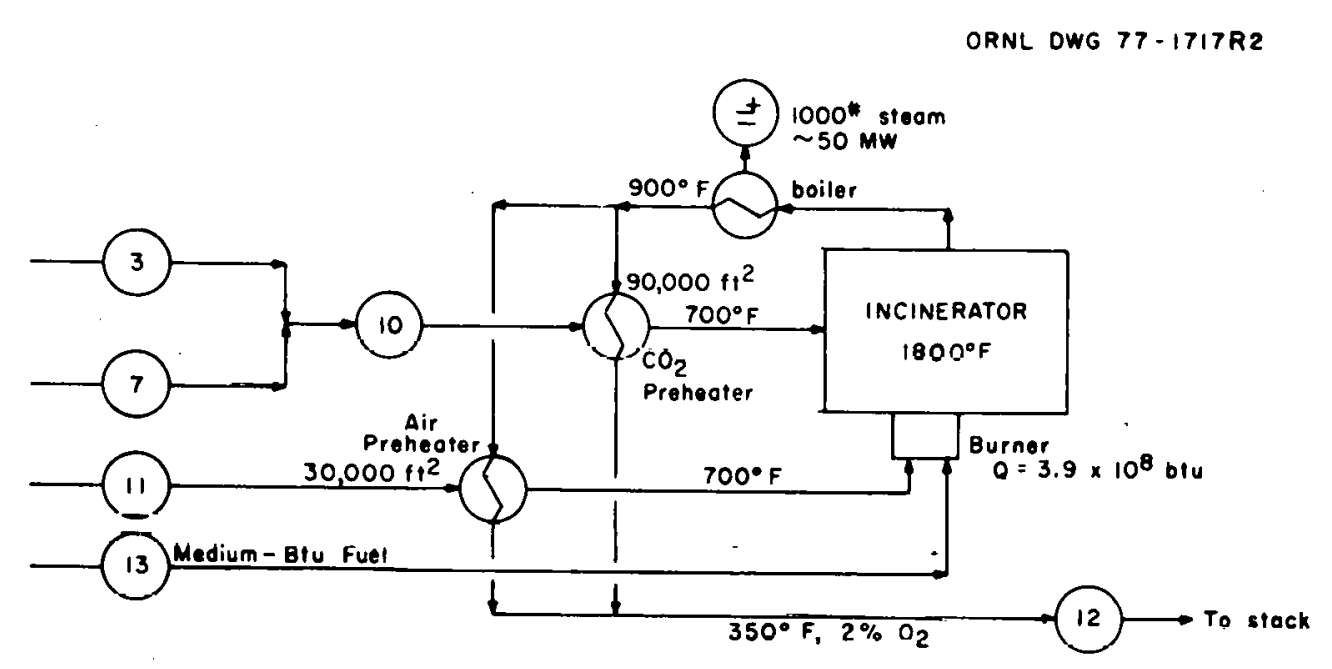

APPROXIMATE COMPONENT FLOWS FOR EQUIPMENT SIZING, LB-MOLES/HOUR:

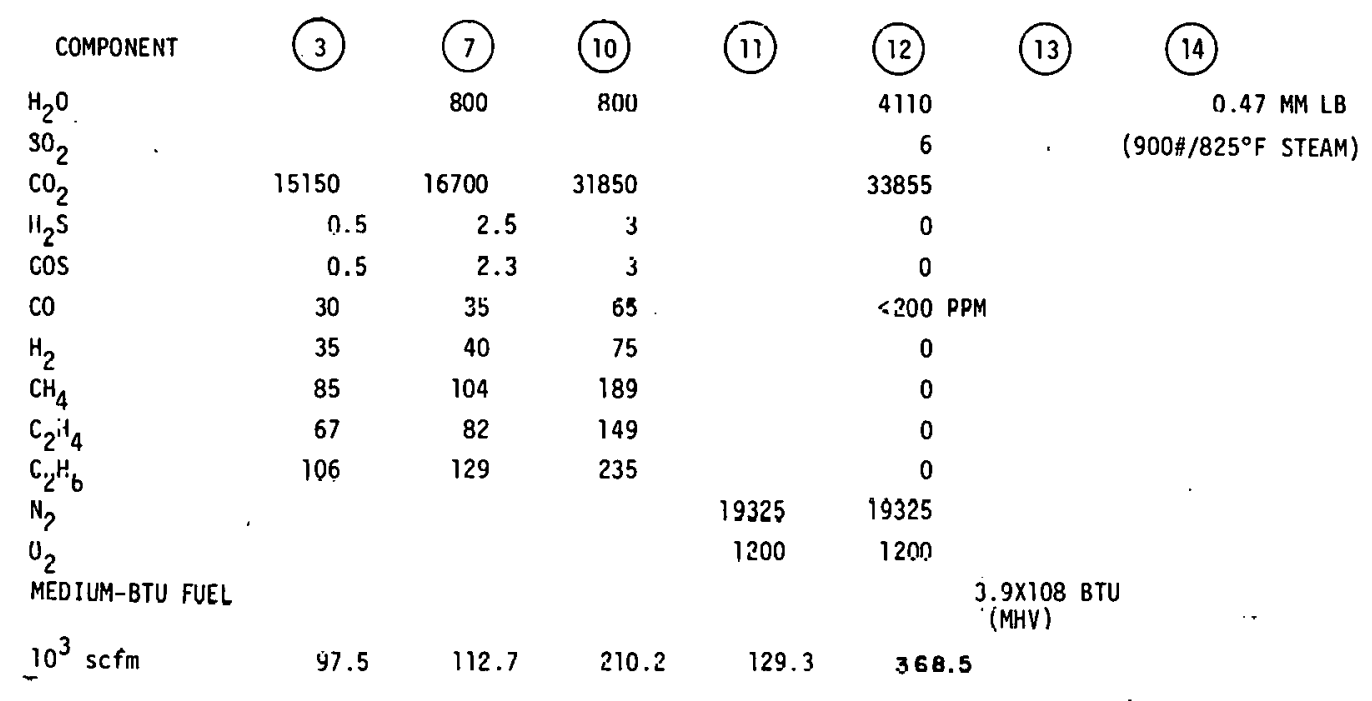

Fig, 1.2: Tnrineration in a medium-Btu gas-fired boiler. 
boiler are heated to $\sim 700$ to $800^{\circ} \mathrm{F}$ by heat exchange, the calculated combustion temperature for the tail gases is $21300^{\circ} \mathrm{F}$. The additional heat required to increase this temperature to $1600^{\circ} \mathrm{F}$ must be supplied by medium-Btu gas. This amounts to $4.40 \times 10^{8}$ Btu of sulfur-free synthesis gas per $\mathrm{hr}$, which costs about $\$ 3.50 / 10^{6} \mathrm{Btu}$. Steam production from the combustion of the tail gases and medium-Btu gas is $\sim 600 \mathrm{million} \mathrm{Btu} / \mathrm{hr}$, but the value of the steam is only $\$ 1.27 / 10^{6} \mathrm{Btu}$, leaving an energy cost deficit of about $\$ 7$ million/year.

The cost of the incinerator-boiler system was estimated at $\$ 6$ million, based on scaled-down gas-fired boiler data ${ }^{7}$ and on estimates obtained from the J. Zink Company. ${ }^{8}$

\subsubsection{Catalytic incineration}

Fig. 4.3 shows the flowsheet used for estimating capital and operating costs. Catalyst-bed inlet and outlet temperatures are $700^{\circ} \mathrm{F}$ and $900^{\circ} \mathrm{F}$, respectively. In normal operation, the exothermic heat of oxidation of the $\mathrm{CO}$ and hydrocarbons is sufficient to supply the heat requirements of the process. An auxillary heater is required for startup. A venturi ejector is used to recycle hot gases to the catalyst bed to help maintain its operating temperature. The heat contained in the net hot gases leaving the bed is used to preheat the feed gas before the exit gases are discharged to the stack. The discharge temperature of the stack gas is kept above $400^{\circ} \mathrm{F}$ to prevent downdrafting. The principal utility consumer in the process is the feed-gas blower.

A space velocity of $b 000$ scf. per hr per $\mathrm{ft}^{3}$ of reactor was used for estimating the required catalyst-bed volume. The space velocity recommended by Air Resources was $15,000 \mathrm{scf} / \mathrm{hr} / \mathrm{ft}^{3}$, but we felt that a lower figure was justified in view of the uncertaintles in catalyst life and hydrocarbon burnout rates. Catalyst costs were based on data obtained from Air Resources. Heat recovery temperatures were low enough to be witliu the range of currently avallable equipment.

The capital cost of catalytic incineration is estimated at $\$ 14$ million. Operating costs are estimated at $\$ 2.9 \mathrm{million} /$ year, most of which is electricity used for driving the inlet gas blower. A credit 
ORNL DWG 77-1718R

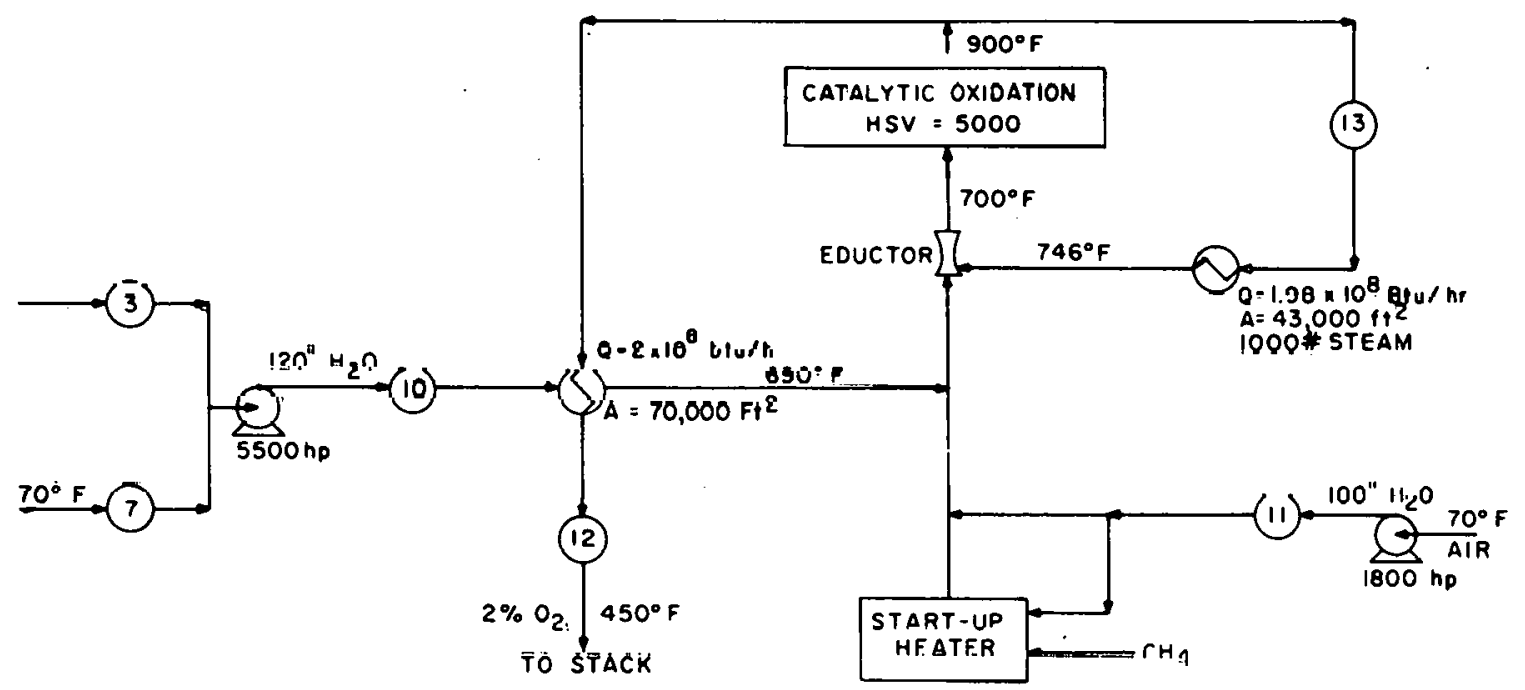

APPROXIMATE COMPONENT FLOWS FOR EQUIPMENT SIZING, LB-MOLES/HOUR:

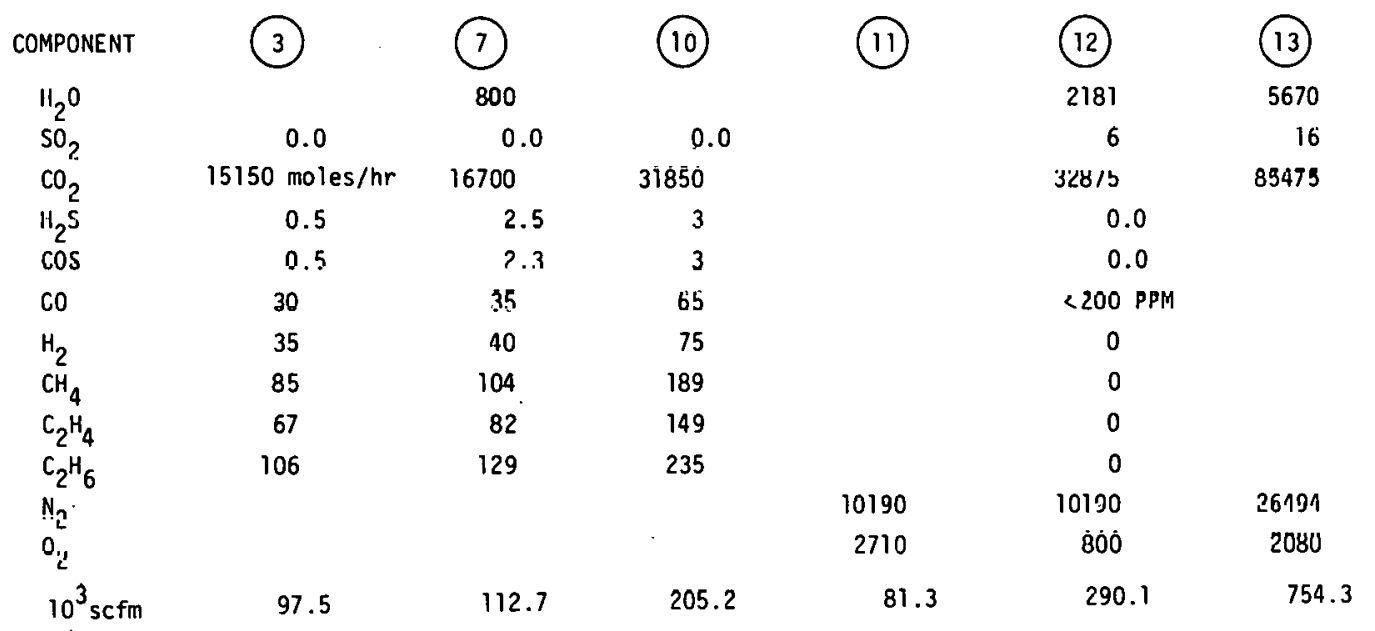

Fig. 4.3. Incineration in a catalyst bed. 
of $\$ 1.8 \mathrm{million} /$ year for steam production reduces the net operating cost to $\$ 1.1 \mathrm{million} /$ year.

Catalytic incineration is still in the developmental stage for the application considered here, although it has been used to a limited extent in industry for the destruction of potential atmospheric contaminants. ${ }^{15}$ In the past, catalyst performance has not always been as reliable as desired, probably due to the presence of poisons in the gas streams. Consequently, when the cleanup of contaminants is mandatory, thermal incineration has more frequently been the choice of plant operators. Heavy metals, halides, and sulfur are typical poisons. The platinum group catalysts are permanently poisoned by heavy metals and temporarily by halides and sulfur, and they tend to oxidize sulfur to $\mathrm{SO}_{3}$. For the application contemplated here, Engelhard advises that catalyst activity and life cannot be predicted without testing under conditions which approximate those expected in the plant. ${ }^{16}$ Catalytic incineration is employed in cases where the market has justified the development costs. Two important applications are in automobile emissions exhaust control and in the destruction of $\mathrm{NO}_{\mathrm{x}}$ in nitric acid plants.

Air Resources ${ }^{15}$ has a commercial catalytic system which has been used to catalytically incinerate hydrocarbons, chlorlnated hydrocarbons, and mercaptans in certain types of gases. The catalyst is reported to be resistant to heavy metals and phosphates. The system is currently being tested in the dusty off-gases from both the sintering steps at a steel plant and a lead-melting operation. The formation of $\mathrm{S}_{3} \mathrm{~s}_{3}$ as a resull of sulfur compound destruction appears to be negligible at temperatures below $1000^{\circ} \mathrm{F}$. The upper operating temperature for the catalyst is $\sim 1200^{\circ} \mathrm{F}$.

\subsubsection{Incineration - Aqua Claus process}

The Aqua Claus process is currently under development. If euccessful, it will permit reaction of a gas stream containing $\mathrm{SO}_{2}$ with a $\mathrm{H}_{2} \mathrm{~S}-\mathrm{rich}$ stream in a 1 iquid-phase reactor to produce sulfur. 
Although the objectives of this study did not include $\mathrm{SO}_{2}$ removal, it was felt that it would be useful to indicate how a process such as Aqua Claus might be used in conjunction with catalytic incineration to remove $\mathrm{SO}_{2}$ from the incinerated gases. In this study, therefore, the Aqua Claus option is an add-on to the incineration option, with the purpose of eliminating all or part of the $\mathrm{SO}_{2}$ emissions from the incinerator.

The process flow diagram shown in Fig. 4.4 indicates how the Aqua claus option might be used. The flow plan shown represents a major revision to the standard uanner of trearment used in the WESCO plant. The Claus plant and the Stretford plant have bean eliminated. Feed streams 3, 4, 5, and 6 come trom the Rectigol unit and the $\mathrm{H}_{7} \mathrm{~S}$ concentrator. All the hydrocarbon-contaminated gases except the concentrated $70 \% \mathrm{H}_{2} \mathrm{~S}$ stream from the Rectisol unit (stream 5) are incinerated to $\mathrm{SO}_{2}$. The $\mathrm{SO}_{2}$-rich tail gas is reacted with $\mathrm{H}_{2} \mathrm{~S}$ in the Aqua Claus system, the $\mathrm{H}_{2} \mathrm{~S}$ being provided by the $70 \% \mathrm{H}_{2} \mathrm{~S}$ stream. The unreacted contaminants in the $70 \% \mathrm{H}_{2} \mathrm{~S}$ stream are returned to the catalytic inoinerator. Treatment of the flue gases from the boiler plant is not included in this flowsheet; it is assumed that flue-gas desulfurization would continue to be used for this stream.

The economics of this method of treatment is not well defined since coste for the Aqua Claus process are nut yet available. Indications are that the Aqua Claus plant might cost about as much as a Stretford unit, or perhaps $25 \%$ more. A rough cost summation of the route shown in Fig. 4.4 was made by estimating $\$ 20$ million for the Aqua Claus unit ${ }^{17}$ and $\$ 14$ million for catalytic incineration, then subtracting $\$ 15$ million for the Stretford unit and $\$ 6$ million for the Claus plant, giving a net increase of $\$ 13$ million above the base case.

A potential future advantage for the Aqua Claus route is that it offers the possibility of treating the bollut flue gases as well as the other streams shown. If this potential is ever achieved, a substantial reduction in the $\mathrm{SO}_{2}$ emissions from the overall facility may be possible. In the flowsheet shown, the $\mathrm{H}_{2} \mathrm{~S}-\mathrm{rich}$ stream from the Rectisol unit is not large enough to permit the multigas stream treatment. 


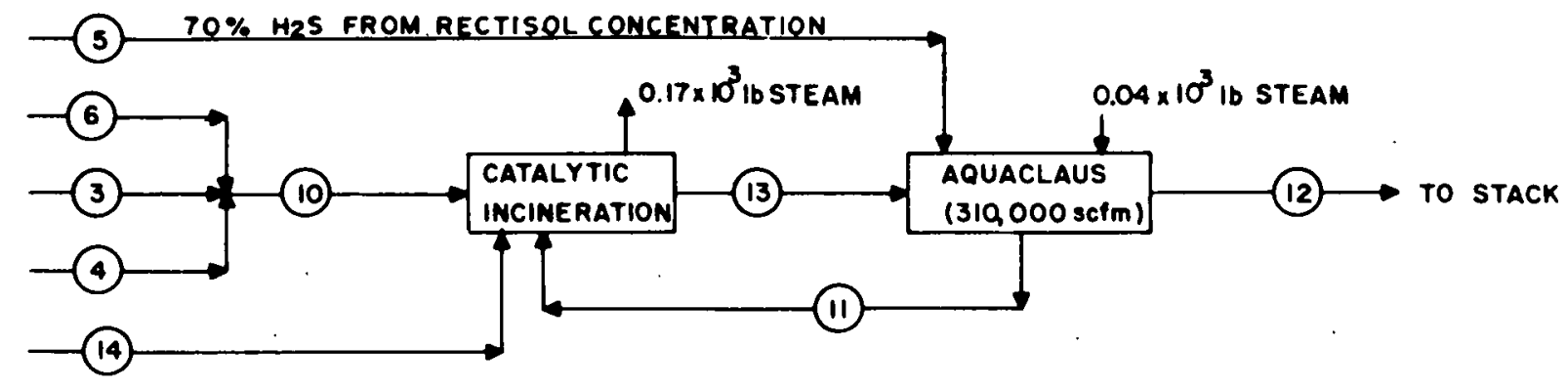

APPROXIMATE COMPONENT FLOWS FOR CAPITAL COST ESTIMATION, LB-MOLES/HOUR:

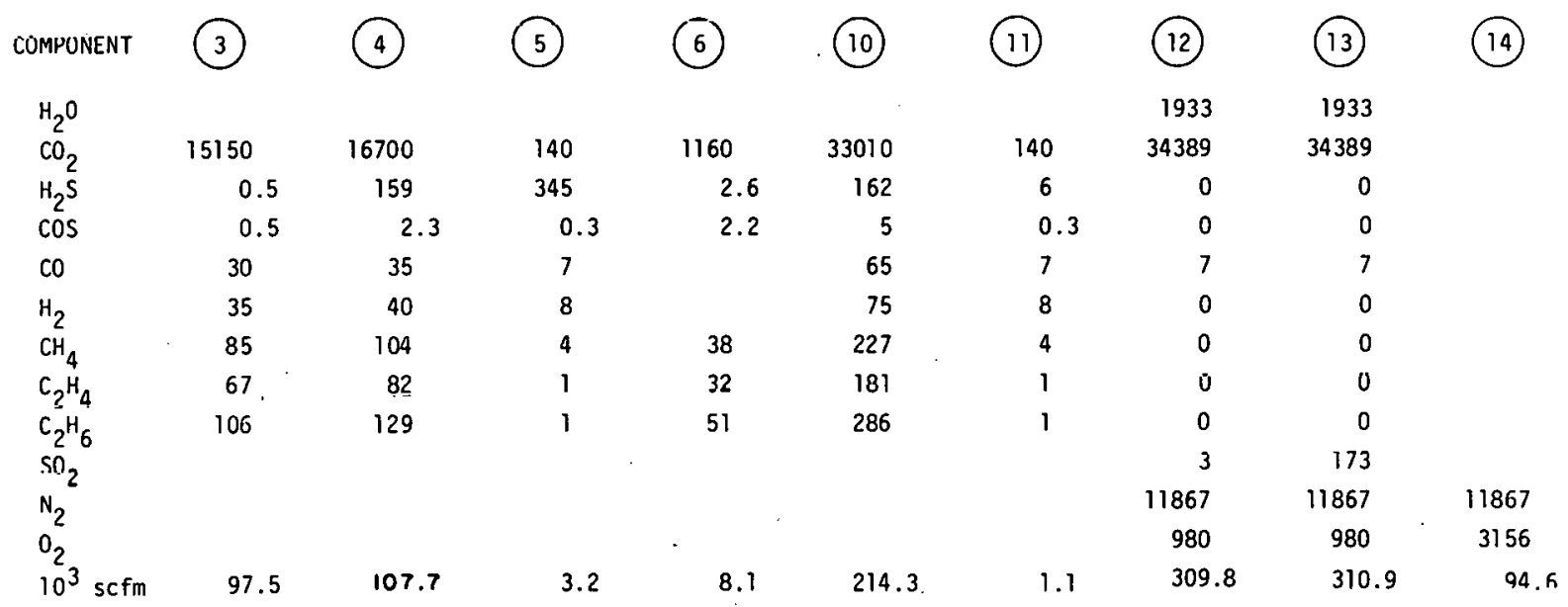

Fig. 4.4. Satalytic incineration with Aqud Claus absorber. 


\subsubsection{Absorption (hot carbonate process)}

Figure 4.5 shows how hot carbonate absorption might be used to treat the $\mathrm{CO}_{2}$-rich streams. Hot carbonate solution absorbs both $\mathrm{H}_{2} \mathrm{~S}$ and $\mathrm{CO}_{2}$. Most of the $\mathrm{CO}$ and hydrocarbons are not absorbed and are recycled to the Rectisol unit (stream 14). The small amounts of c0 and hydrocarbons that are absorbed are released by flashing the solution at a lower pressure and are then recycled to the absorber. Eventually, due to readjustment of concentrations in the absorber, this material discharges with stream 14. Another adjustment of concentrations cakes place in the Rectisol unit through the buildup of recycled co and hydrocarbons, resulting in the discharge of these components with the treated product gas stream (stream 9 in Fig. 3.1).

Aqueous inorganic chemlcal absorption systems pick up relatively little of the hydrocarbons or $\mathrm{CO}$ entering with the $\mathrm{CO}_{2}$. However, sufficient amounts of $\mathrm{CO}$ and hydrocarbons are dissolved in the water for a two-stage flash recycling $\sim 15 \%$ of the absorbed $\mathrm{CO}_{2}$ to be required in order to decontaminate the liquor going to the stripper.

Hydrogen sulfide reacts with the hot carbonate along with the $\mathrm{CO}_{2}$. The rate at which $\mathrm{H}_{2} \mathrm{~S}$ dissolves in a catalyst-free carbonate solution is many time greater than that of the $\mathrm{CO}_{2}$. The lower portion of the absorber system shows a section where $\mathrm{H}_{2} \mathrm{~S}$ is absorbed in the aqucouo carbonate. This liquor flows to an independent stripper. The $\mathrm{H}_{2} \mathrm{~S}-\mathrm{rich}$ overhead from the stripper is routed back to the stretford plant.

The $\cos$ is relatively insoluble; however, when it diocolves, it slowly hydrolyzes to $\mathrm{H}_{2} \mathrm{~S}$. As a result, the liquor leaving the bottom of the $\mathrm{CO}_{2}$ absorber will contain a lurge fraction of the $H_{2} \mathrm{~S}$ that was formed from the cos. Since little of the $\mathrm{H}_{2} \mathrm{~S}$ formed from $\cos$ is lost in the flash, the $\mathrm{CO}_{2}$ stream (stream 12) cannot be completely decontaminated. A few ppm of sulfur will always be encountered. Standards proposed by EPA specify whether the sulfur should be completely removed or oxidized to $\mathrm{SO}_{?}$. A possible solution is to reduce the $\mathrm{H}_{2} \mathrm{~S}$ content of the $\mathrm{CO}_{2}$ stream to $\sim 0.1 \mathrm{ppm}$ by reaction with $\mathrm{ZnO}$ at a temperature in the range of 300 to $500^{\circ} \mathrm{F}$. By using heat exchange, the auxiliary fuel requirements can be kept to very low levels. 


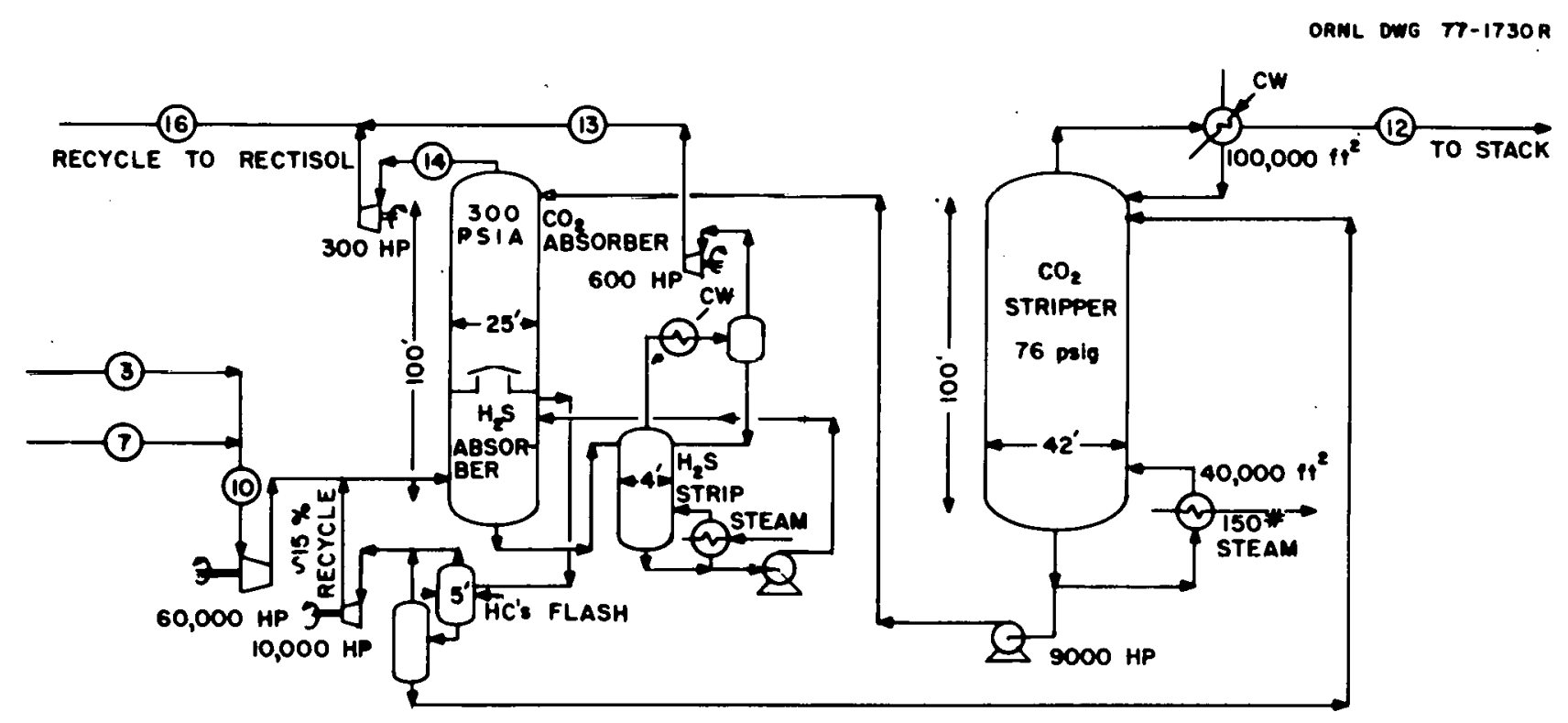

APPROXIMATE COMPONENT FLOWS FOR EQUIPMENT SIZING, LB-MOLES/HOUR:

\begin{tabular}{|c|c|c|c|c|c|c|c|c|}
\hline COMPONENT & (3) & (7) & (10) & (12) & (13) & (14) & (16) & \multirow{11}{*}{$\begin{array}{l}\text { STREAM } 12 \mathrm{MnY} \\
\text { SIILL NEED } \mathrm{ZnO} \\
\text { TREATMENT FOR } \mathrm{H}_{2} \mathrm{~S} \\
\text { ELIMINATION }\end{array}$} \\
\hline $\mathrm{H}_{2} \mathrm{O}$ & & 800 & 800 & 2000 & & 2 & & \\
\hline $\mathrm{CO}_{2}$ & 15150 & 16700 & 31850 & 31.250 & 300 & 300 & 600 & \\
\hline$H_{2} S$ & 0.5 & 2.5 & 3 & 0.1 & \multirow[t]{2}{*}{2.9} & 0 & 2.9 & \\
\hline $\cos$ & 0.5 & 2.3 & 3 & 0.1 & & 2.9 & 2.9 & \\
\hline $\mathrm{CO}$ & 30 & 35 & 65 & & & 65 & 65 & \\
\hline $\mathrm{H}_{2}$ & 35 & 40 & 75 & & & 75 & 75 & \\
\hline $\mathrm{CH}_{4}$ & 85 & 104 & 189 & & & 189 & 189 & \\
\hline $\mathrm{r}_{2} \mathrm{H}_{4}^{4}$ & 67 & 82 & 149 & 1.5 & & 147.5 & 147.5 & \\
\hline $\mathrm{C}_{2} \mathrm{H}_{6}$ & 106 & 129 & 235 & 1.0 & & 2.34 & 234 & \\
\hline $10^{3} \mathrm{scfm}$ & 97.5 & 112.7 & $210 . ?$ & 209.5 & 1.9 & 6.4 & 8.3 & \\
\hline
\end{tabular}

Fig, 4.5. Hot carbonate absorption of acid gas. 
Another approach, which would be more economical, is to use selective catalytic incineration of the $\mathrm{H}_{2} \mathrm{~S}$ and $\cos$. This has the advantage of meeting the requirement that all sulfur releases be in the form of $\mathrm{SO}_{2}$.

Capital cost estimates for the process route shown in Fig. 4.5 were developed from estimates of major item costs and by scaling 11terature values. 17 A price of $\$ 25$ million was estimated for a single train without selective $\mathrm{H}_{2} \mathrm{~S}$ absorption or hydrocarbon flashing. The additional $\mathrm{H}_{2} \mathrm{~S}$ absorption section and the flash vessels were estimated to increase the cost by $\sim 30 \%$. The Zno chemical absorption system was estimated at about \$5 million, giving a total plant cost of about $\$ 38$ million.

Operating costs for this route are very hilgh due to the large amounts of utilities consumed in the absorption and regeneration steps. In view of the large capital and operating costs, the economics of this route is very unfavorable.

\subsubsection{Absorption (cold water)}

A technique employed by industry for removing relatively small amounts of acid gases from gas streams such as natural gas is highpressure absorption of the gas contaminants in water by countercurrent contact in packed towers. ${ }^{18}$ Application of this principal to the decontamination of the effluent streams requires the absorption of nearly all the $\mathrm{CO}_{2}, \mathrm{H}_{2} \mathrm{~S}, \mathrm{C}_{2} \mathrm{H}_{4}$, and $\mathrm{C}_{2} \mathrm{H}_{6}$. However, the solubilities of the gases are quite low even at high pressures. These low solubilities, coupled with the very large amount of $\mathrm{CO}_{2}$, present cwo disadvantages for this method of effluent decontamination: (1) the need for very large and expensive equipment, and (2) high electric power costs for recirculating the water.

The advantages of the water absorption system uver other aqueous systems for flue-gas decontamination are: a simple plant design, very inexpensive absorbent, and no heat exchanger requirements.

I'wo pressure reduction flash stages are used to lower the hydrocarbon concentration $\left(\mathrm{C}_{2} \mathrm{H}_{4}\right.$ and $\left.\mathrm{C}_{2} \mathrm{H}_{6}\right)$ of the $\mathrm{CO}_{2}$-rich water solution from the absorption tower. The flashed hydrocarbons, along with a portion of the $\mathrm{CO}_{2}$, are recompressed and recycled to the absorber inlet. 
Approximately $20 \%$ of the gas stream is recycled to reduce the nonmethane hydrocarbon content of the $\mathrm{CO}_{2}$ effluent gas stream to $<100$ ppm (maximum EPA limits). Power recovery turbines are used at each of the pressure reduction flash stages to recover part of the power that is required for pumping the absorber water. It is estimated that 45 to $50 \%$ of the pumping power may be recovered.

The $\mathrm{CO}_{2}$-rich water stream is stripped of $\mathrm{CO}_{2}$, and $\mathrm{H}_{2} \mathrm{~S}$ by flashing to atmospheric pressure. The desorption is supplemented by air stripping to adequately lower the gas concentration of the water before it is recycled. Another disadvantage of the water absorption system is that the $\mathrm{CO}_{2}$ effluent stream from the stripping tower contains $\mathrm{H}_{2} \mathrm{~S}$ and will require desulfurization or conversion to $\mathrm{SO}_{2}$.

Due to their low solubilities, only traces of $\operatorname{COS}, \mathrm{CO}, \mathrm{H}_{2}$, and $\mathrm{CH}_{4}$ are absorbed by the water. These gases combined with the nonmethane hydrocarbon gases from the flash stages and some $\mathrm{CO}_{2}$ leave the top of the absorption tower and are recycled to the Rectisol system or used as fuel. Based on the higher heats of combustion for the gas components of recycle stream, the heating value is $\sim 3700 \mathrm{Btu} / \mathrm{lb}$.

Corrosion may be a problem due to the high concentration of $\mathrm{CO}_{2}$ in water. Assessment in terms of corrosion rate must be determined. However, corrosion inhibitors can be effectively used along with stainless steel in potentially susceptible areas, and interior coatings can be employed for the contact towers.

Capital costs for the water absorption process were developed from the major equipment 1tems based on in-house cost data. The estimated overall cost was $\$ 66$ million.

\subsubsection{Removal of $\mathrm{CO}$ by cuprous ammonium carbonate solution}

The absorption of $\mathrm{CO}$ by cuprous ammonium solutions ${ }^{19}$ has been extensively used in the purification of ammonium synthesis gas. The absorptiun process is capable of lowering the CO content of the synthesis gas to <10 ppm when carried out at high pressure in a countercurrent contactor. This process would be employed in addition to another effluent purification process which does not remove $\mathrm{CO}$, such as a molecular sieve system. 
The generally accepted absorption reaction for the cuprous ammonium salt solution is shown below:

$$
\mathrm{Cu}\left(\mathrm{NH}_{3}\right)_{2}^{+}+\mathrm{NH}_{3}+\mathrm{CO} \rightarrow \mathrm{Cu}\left(\mathrm{NH}_{3}\right)_{3}(\mathrm{CO})^{+} \text {. }
$$

The carbonate system was selected over the formate or acetate solution for this preliminary evaluation because the operating costs are less and the effluent stream to be treated has a high $\mathrm{CO}_{2}$ content. Operating data for carbonate systems indicate that a sat1sfactury $\left(\mathrm{CO}_{3}\right)^{2-}$ cquilibrium can be maintained by the absorption of $\mathrm{CO}_{2}$ from the gas being treated and the evolution of an equal quantity during regeneration.

A simplified flow diagran for the aboorption of co from the effluent gas stream 11 is presented in Fig. 4.6. The system encompasses the Co absorber, regenerator, $\mathrm{NH}_{3}$ recovery unit, residual $\mathrm{CO}$ oxidizer, and regenerated absorption solution cooler.

The feed gas to the absorber must be sulfur-free because sulfur compounds $\left(\mathrm{H}_{2} \mathrm{~S}, \mathrm{COS}\right.$, etc.) are deleterious to the fonic equilibrium of the system. The copper sulfide precipltate that would form in the presence of sulfur would eventually plug the absorber unit. In evaluating this process for treatment of the effluent gas stream 11 it is assumed Lhal: (1) the large amoune nf $60_{2}$ wlll lot upset the system equilibrlum or prevent the absorption of $\mathrm{CO}$, (2) the side reactions between $\mathrm{CO}_{2}$ and the ammonium lons in the absorption solution forming ammonium bicarbonate and carbonate will not prevent regeneration of the absorption colution to the original ionic spectes, and (3) the absorpclou of $\mathrm{CO}_{2}$ into the cuprous ammonium solution can be extrapolated from normal operating pressures of $\sim 1700$ psia to the destred pressure of 300 psia. These assumptions will have to be resolved before the prucess can bc employed for removal of co from the effluent stream.

The overhead vapor from the regenerator will contain 7 to $8 \%$ CO in $\mathrm{CO}_{2}$ and can be recycled as additional raw gas feed to the shift conversion unit.

Carbon steel is generally considered satisfactory for cuprous ammonium salt solutions, but the presence of $\mathrm{CO}_{2}$ will result in corrosion conditions in the vapor sections of the system. Stainless steel is recommended for the corrosive areas. 
ORNL OWG TT-174IR

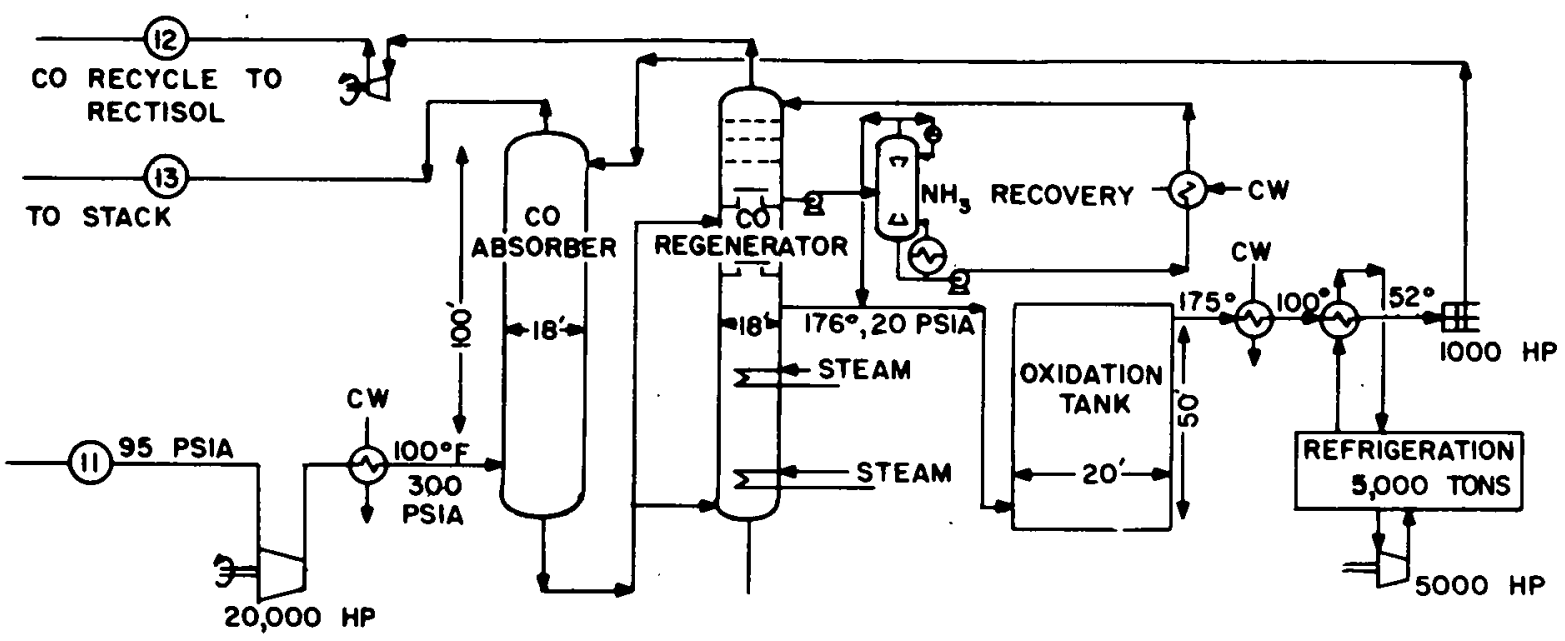

STREAM (11) MUST BE FREE OF H 5 AND COS. THIS PROCESS WILL BE AN ALTERNATE ADD-ON TO ADSORPTION ON MOLECULAR SIEVES TO REMOVE THE CO APPROXIMATE COMPONENT FLOWS FOR CAPITAL COST ESTIMATION, LB-MOLES/HOUR:

$\begin{array}{lccc}\text { COMPONENT } & 11 & 12 & 31050 \\ \mathrm{H}_{2} \mathrm{O} & 31850 & 800 & 0 \\ \mathrm{CO}_{2} & 0 & 0 & 0 \\ \mathrm{H}_{2} \mathrm{~S} & 0 & 0 & 0 \\ \mathrm{COS} & 65 & 65 & 75 \\ \mathrm{CO} & 75 & & 189 \\ \mathrm{H}_{2} & 189 & & 1.5 \\ \mathrm{CH}_{4} & 1.5 & & 1 \\ \mathrm{C}_{2} \mathrm{H}_{4} & 1 & & 197,3 \\ \mathrm{C}_{2} \mathrm{H}_{6} & 202.7 & 5.4 & \\ 10^{3}{ }_{\text {scfm }} & & & \end{array}$

Fig. 4.6. Cuproammonium complexing of $\mathrm{CO}$. 
The capital cost for the auxiliary process to remove co from the partially decontaminated effluent stream was estimated at $\$ 20$ million. An additional $\$ 5$ million would be needed for a hot $\mathrm{ZnO}$ process to remove the traces of sulfur compounds from the feed gas stream, giving a total estimated capital cost of $\$ 25$ million. This estimate was determined from major equipment items and in-house cost data.

\subsubsection{Adsorption}

An unsuccessful search was made for an adsorbent capable of removing CO and nonmethane hydrocarbons from a $\mathrm{CO}_{2}$-rich gas. Also, adsorbents with sufficient selectivity to separate $\mathrm{CO}_{2}, \mathrm{C}_{2} \mathrm{H}_{4}$, and $\mathrm{C}_{2} \mathrm{H}_{6}$ do not appear to exist. The two best candidates are activated carbon and molecular sieves, which are about equally effective on a capacity basis. However, if the pore size of the sieve exactly matches the molecular size of the species being adsorbed, the adsorption capacity may be increased several fold.

In the application envisaged here, it was assumed that adsorption would be used to remove the nonmethane hydrocarbons and that a separate supplemental add-on process such as cuprous ammonium absorption would be used to remove the co. However; the economics of this route is unfavorable, basically because the adsorption capacities for $\mathrm{C}_{2} \mathrm{H}_{4}$ and $\mathrm{C}_{2} \mathrm{H}_{6}$ are poor, even at temperatures ás $10 \mathrm{w}$ as $-50^{n} \mathrm{~F}$. Luwer Lemperatures are not posaiblc due to the liquefaction of $\mathrm{CO}_{2}$. Operation at $100^{\circ} \mathrm{F}$ (to eliminate the cost of refrigeration) would require working pressures in the range of 1000 to 2000 psig in order to obcain working capacities equivalent to those at $100 \mathrm{psig}$ and $-50^{\circ} \mathrm{F}$. A rough estimate based on acrivated carbun indicated a capacity of $0.3 \mathrm{lb}$ of $\mathrm{C}_{2} \mathrm{H}_{6}$ per $100 \mathrm{lb}$ of carbon. 20

To determine whether the development of improved adsorbents has any economic promise in this application, an adsorbent was hypothesized which has a capacity of $1.5 \mathrm{lb}$ of $\mathrm{C}_{2} \mathrm{H}_{6}$ per $100 \mathrm{lb}$ of adsorbent. A scheme using this material in a fixed-bed cyclic process at $100 \mathrm{ps} 1 \mathrm{a}$ and $-50^{\circ} \mathrm{F}$ is shown in Fig. 4.7. The diagram does not show the very complex manifolding system that is required in actual operation. No attempt was made to include the unsteady-state heating and cooling effects which take place as the beds are cycled from adsorption to regeneration to cooling. Heat exchangers were sized on a steady-state basis. 


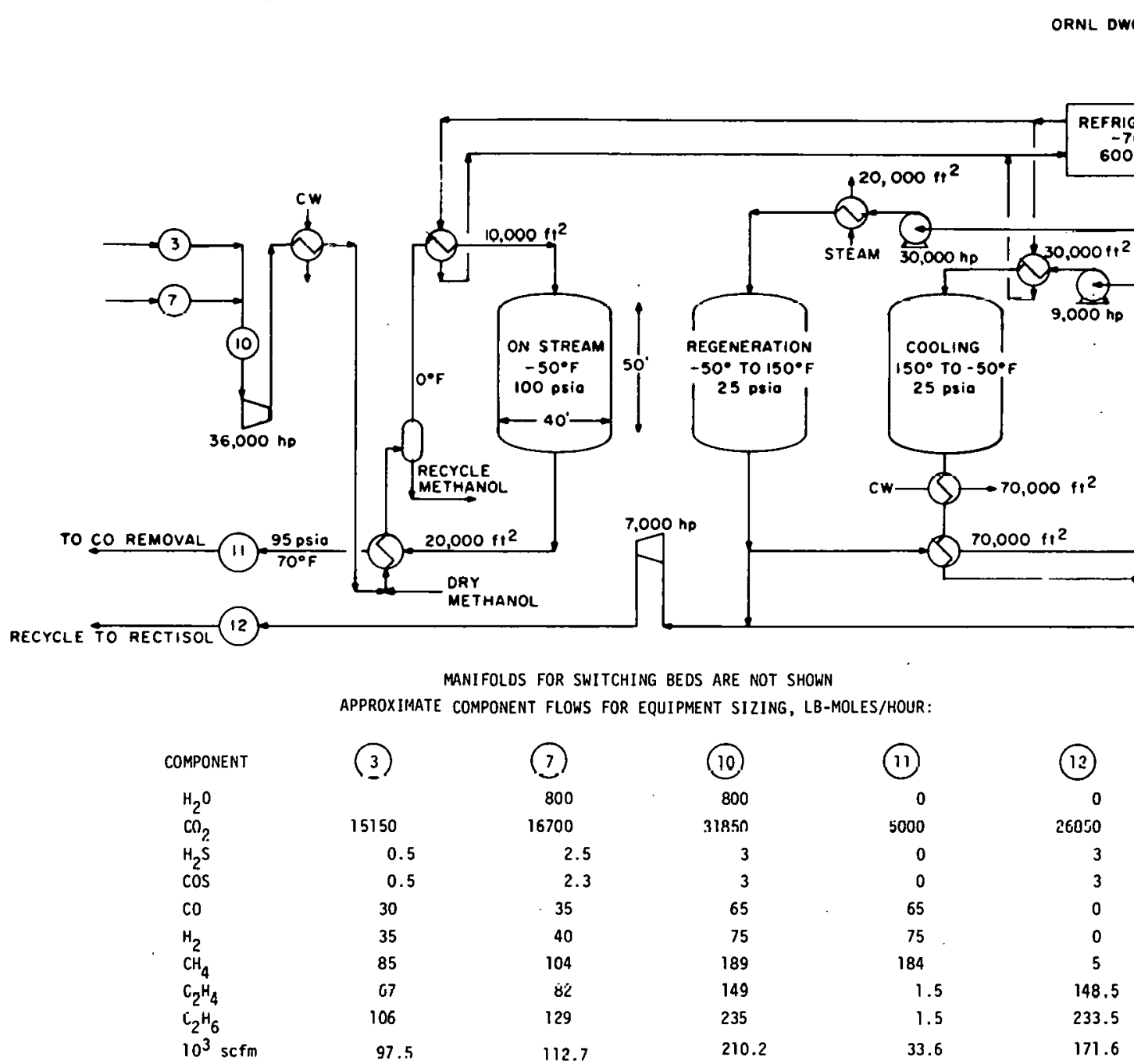

Fig. 4.7. Absorption at low temperatures. 
Based on a cost of $\$ 50$ million for major equipment items, which is probably a low estimate, and an energy cost roughly equal to the value of the impure synthesis gas recovered, $\$ 8$ million per year, even a very selective adsorbent process would be extremely expensive. An additional capital cost of $\$ 20$ million for an add-on system such as cuprous ammonium carbonate to remove $C O$ from the vent-gas stream would have to be coupled to the above cost to complete the decontamination.

\subsubsection{Cryogenic separation (liquefaction-distillation)}

A simplified flowsheet of a proposed low-temperature liquefactiondistillation process is presented in Fig. 4.8 for separating and recovering the hydrocarbons and $c U$ air pollutanls pieseint in the Lurgi process tail gas. In this scheme, the contaminated feed gas is compressed and cooled to liquefy nearly all the $\mathrm{CO}_{2}, \mathrm{H}_{2} \mathrm{~S}, \mathrm{C}_{2} \mathrm{H}_{4}, \mathrm{C}_{2} \mathrm{H}_{6}$, and possibly some $\mathrm{CH}_{4}$. The liquid phase is separated from the noncondensables $\left(\mathrm{H}_{2}, \mathrm{CO}\right.$, and residual $\mathrm{CH}_{4}$ ) and fractionated in the first distillation tower for separation of the $\mathrm{CH}_{4}, \mathrm{C}_{2} \mathrm{H}_{4}$, and a sulall amount of $\mathrm{CO}_{2}$. In the second distillation tower, the underflow is enriched in $\mathrm{C}_{2} \mathrm{H}_{6}$ and contains the $\mathrm{H}_{2} \mathrm{~S}$ and $\mathrm{COS}$, whereas the overhead distillate is essentially all $\mathrm{CO}_{2}$ and will comply with EPA air quality standards when subsequently vented to the a timosphere.

The streams enriched in $\mathrm{C}_{2} \mathrm{H}_{4}$ and $\mathrm{C}_{2} \mathrm{H}_{6}$ from the distillation towers are combined with the noncondensable gases and recycled to the Rectisol unit.

In the $\mathrm{C}_{2} \mathrm{H}_{4}-\mathrm{CO}_{2}-\mathrm{C}_{2} \mathrm{H}_{6}$ systcm, the vapor pressure of the $\mathrm{CO}_{2}$ at the separation temperatures and pressures falls between that of the two organics; consequently, two distillation towers are required. In the

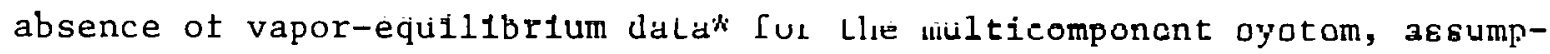
tions were necessary in order to define the preliminaly engineering requirements. It was assumed that: (1) essentially complete separation

\footnotetext{
*Subsequent to the pieparation this manuscript papers on relative vapor equilibrium data were presented at the 70th Annual A.I.Ch.E. Meeting, Nov. 15, 1977. One paper reviewed a six-component simulated sour gas system at subambient temperatures.
} 


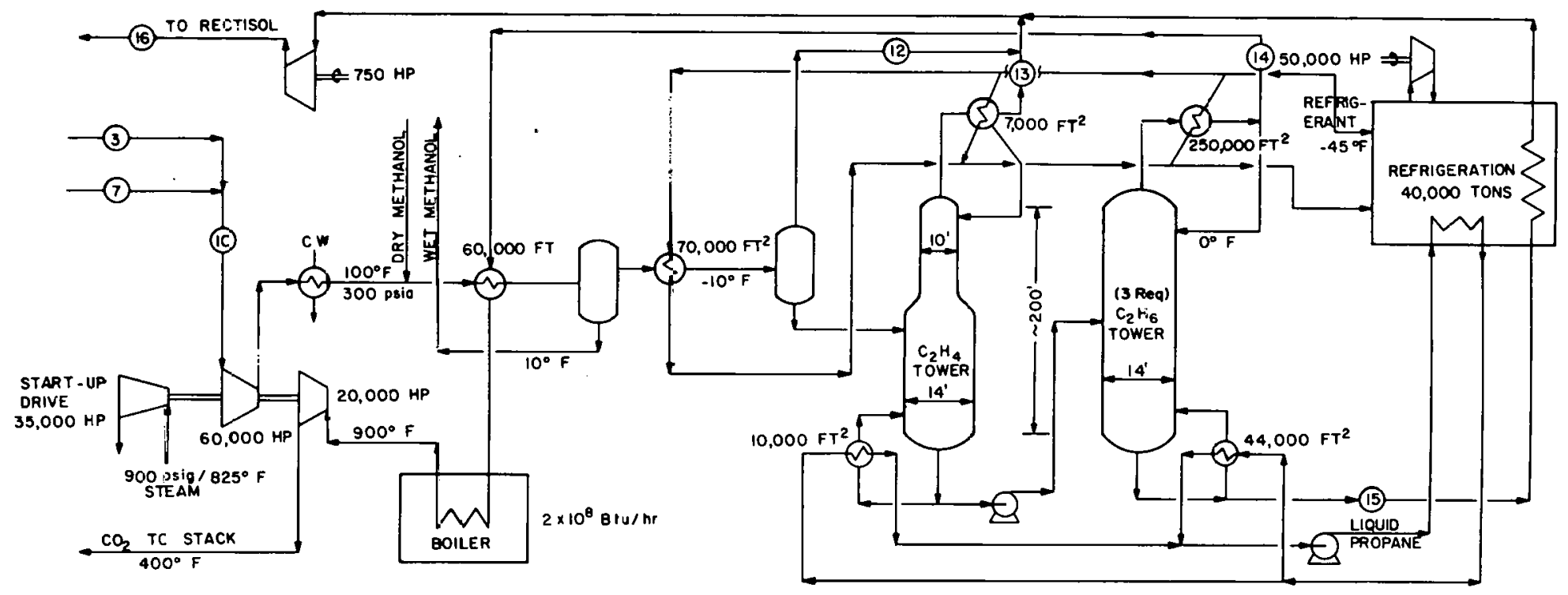

\begin{tabular}{|c|c|c|c|c|c|c|c|c|}
\hline \multirow[b]{2}{*}{ COMPONENT } & \multicolumn{7}{|c|}{ APPROXIMATE COMPOMENT FLOUS FOR EQUIPMENT SIZING, L8-MOLES/HOUR: } & \multirow[b]{2}{*}{ (16) } \\
\hline & (3) & (7) & (10) & (12) & (13) & (14) & (15) & \\
\hline $\mathrm{H}_{2} \mathrm{O}$ & & 800 & & 0 & 0 & J & 0 & 0 \\
\hline $\mathrm{CO}_{2}^{2}$ & 15150 & 16700 & 31850 & 1000 & $3000^{\circ}$ & 24050 & 3000 & 7000 \\
\hline $\mathrm{H}_{c}^{\mathrm{S}} \mathrm{S}$ & 0.5 & 2.5 & 3 & 0 & 0 & 0 & 3 & 3 \\
\hline cors & 0.5 . & 2.3 & 3 & 0 & 0 & 0 & $\mathbf{3}$ & 3 \\
\hline co & 30 & 35 & 65 & 30 & 35 & 0 & 0 & 65 \\
\hline $\mathrm{H}_{2}$ & 35 & 40 & 75 & $(50)^{\mathrm{a}}$ & (25) & 0 & 0 & 75 \\
\hline $\mathrm{CH}_{4}$ & 85 & 104 & 189 & (20) & (179) & 0 & 0 & 189 \\
\hline$c_{2} \mathrm{H}_{4}$ & 67 & 82 & 149 & 0 & 147.5 & 1.5 & 0 & 147.5 \\
\hline$c_{2}^{2} H_{6}$ & 106 & 129 & 235 & 0 & 0 & 1.5 & 233.5 & 233.5 \\
\hline $103 \mathrm{sc} \mathrm{fm}$ & 97.5 & 112.7 & 210.2 & 6.9 & 21.3 & 151.5 & 20.4 . & 48.6 \\
\hline
\end{tabular}

aparenthesis incicate an unmeasured value.

Fig. 4.8. Carbon dioxide liquefaction - distillation process. 
of $\mathrm{C}_{2} \mathrm{H}_{4}$ would be effected in the first tower, (2) the $\mathrm{C}_{2} \mathrm{H}_{6}{ }^{+}$concentration in the $\mathrm{CO}_{2}$ overhead from the second tower would be within the maximum EPA limits, (3) only traces of $\mathrm{H}_{2} \mathrm{~S}$ and $\mathrm{COS}$ would be present in the overhead from the second tower, and (4) component separation factors were extrapolated from vapor-equilibrium data for binary systems. $21-23$

Because of the lack of data, the sizing of the distillation columns is subject to considerable uncertainty. This uncertainty is magnified in the case of the $\mathrm{C}_{2} \mathrm{H}_{6}-\mathrm{CO}_{2}$ column because of the unusually large heating and cooling requirements. The key economic factors for the cryogenic separation syscem are Lilie large capital and operating costs of the distillation towers and the refrigeration plant.

The low processing cemperatures and the nonaqueoue solutions should minimize the corrosion problems. It was therefore assumed that carbon steel would be adequate as a material of construction. The temperatures are not sufficiently low to require the use of stainless steel except perhaps in areas of high vapor velocity.

The capital cost for the cryogenic separation process was estimated to be $\$ 99$ million. This estimate was developed from major equipment items and in-house costing data. A more detalled engineering cvaluation of the process would undoubtedly reveal more efficient arrangements for heat exchange systems and possibly reduce lle reflux ratio in the $\mathrm{C}_{2} \mathrm{H}_{6}-$ $\mathrm{CO}_{2}$ separation tower. However, it is clear that both the capital and operating costs of the system would still be very expensive.

\subsubsection{Permeable membrane separation}

Permeable membranes for separating the common gases are still in the early developmental stage. Packages of membranes having surface areas of $<100$ square feet have been tested; however, the scale of the system for the present application is 28 million square feet.

Two types of membranes may be considered in this context. One is a 1-u-thick silicone rubber polymer cast on a microporous backing. The other is a solution of activated potassium carbonate held wichin the pores of a membrane such as a 1-mil-thick polysulfone ultrafiltration type. ${ }^{9,10}$ These composites are supported on wire screens. 
To obtain more economical diffusion rates, it would be desirable to use extremely thin membrane barriers (e.g., silicone rubber film of $0.1 \mu$ or polysulfone film of $0.1 \mathrm{mil}$ ) on a porous support film. Techniques for preparing such films are still being sought.

A possible application of membrane separation is shown in Fig. 4.9. The flowsheet shows only the removal of $\mathrm{CO}$ and hydrocarbons from a $\mathrm{CO}_{2}-$ rich stream. The product streams from the membrane separation are a $\mathrm{CO}_{2}$ stream containing very small amounts of hydrocarbons and co (stream 13) and a smaller recycle $\mathrm{CO}_{2}$-rich stream containing $295 \%$ of the hydrocarbons and $\mathrm{co}$.

In the application considered in this report, separation of $\mathrm{H}_{2} \mathrm{~S}$ and $\mathrm{CO}_{2}$ is also required, since the feed streams are contaminated with $\mathrm{H}_{2} \mathrm{~S}$. Any $\mathrm{H}_{2} \mathrm{~S}$ in the feed will be found in stream 13. Membrane separation of the $\mathrm{H}_{2} \mathrm{~S}$ and $\mathrm{CO}_{2}$ will require a relatively small amount of membrane surface area per stage but a large number of stages. Because of its complexity, this separation is not shown in Fig. 4.9. However, its cost was included in the overall cost estimate for this option.

Based on a future large-scale, well-developed industry, projected membrane costs were estimated at $\$ 5 / \mathrm{ft}^{2} \cdot{ }^{9}, 10$ The overall process cost on this basis was $\$ 75$ million. 


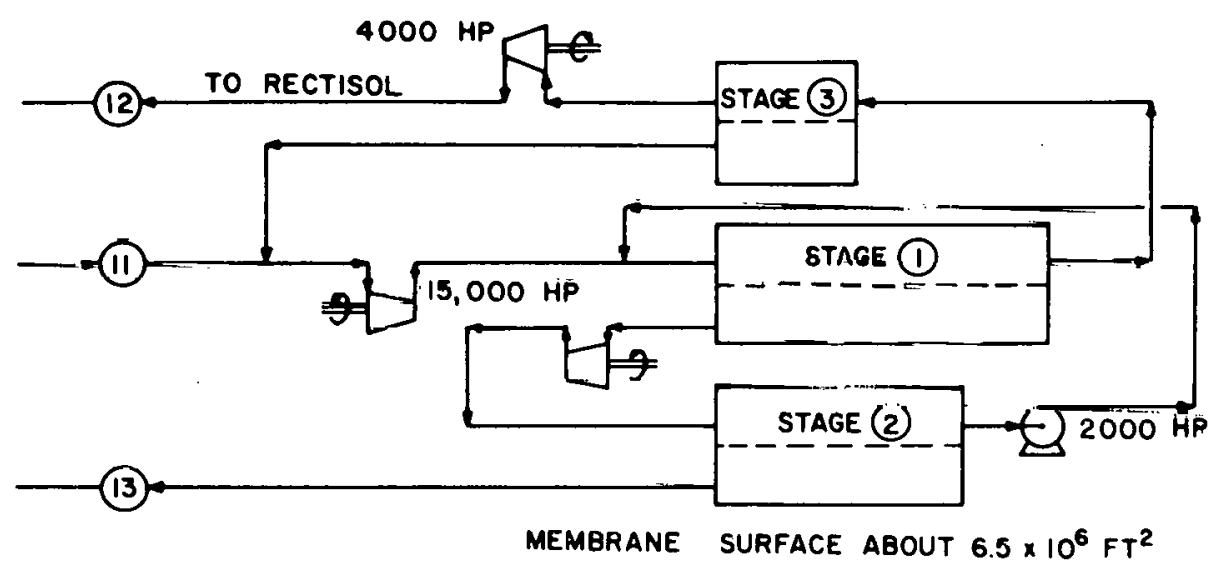

$\begin{array}{lccc}\text { COMPONENT } & 11 & 12 & 13 \\ \mathrm{CO}_{2} \text { MOLES/HOUR } & 31850 & 2000 & 29850 \\ \mathrm{H}_{2} \mathrm{~S} & 0 & 0 & 0 \\ \mathrm{COS} & 0 & 0 & 0 \\ \mathrm{CO} & 6.5 & 00 & 5 \\ \mathrm{H}_{2} & 75 & 71 & 4 \\ \mathrm{CH}_{4} & 189 & 179 & 10 \\ \mathrm{C}_{2} \mathrm{H}_{4} & 1.5 & 0 & 1.5 \\ \mathrm{C}_{2} \mathrm{H}_{6} & 1 & 0 & 1 \\ 105 \text { SC fiII } & 202.7 & 14.6 & 188.2\end{array}$

Fig. 4.9. Permselective membranc relluval of $\mathrm{C} O$. 


\section{APPENDIX}

Basic EPA philosphy requires the maximum economically achievable desulfurization of the boiler flue gas. Sulfur dioxide removal efficiencies for boilers burning 2 to $5 \%$ sulfur coal are between 85 and $95 \%$ for

lime scrubbers. ${ }^{24}$ Assuming that $95 \%$ removal can be guaranteed, the Best Available Technology Economically Achievable standard for $\mathrm{SO}_{2}$ emissions would be 250 ppmv. Based on the results of wet scrubbing with fly ash, ${ }^{25}$ lime scrubbing of the flue gas from a boiler burning $0.8 \%$ sulfur coal may be able to reduce the $\mathrm{SO}_{2}$ to $<100$ ppmv (i.e., $+90 \%$ efficiency).

The sulfur concentration of the Lurgi SNG plant tail gases after reaction with the air necessary to convert the hydrocarbons to $\mathrm{CO}_{2}$ and the sulfur compounds to $\mathrm{SO}_{2}$ is on the order of $150 \mathrm{ppmv}$ of $\mathrm{SO}_{\mathrm{x}}$. If these tail gases are introduced into a boiler employing 2 to $5 \%$ sulfur coal, an increase in total sulfur emissions from the overall plant to the atmosphere will result. The gases will leave at $250 \mathrm{ppmv}$ of $\mathrm{SO}_{2}$ rather than 150 if burned with a clean fuel.

In the case of the low-sulfur coal-fired boiler, a net reduction of $\mathrm{SO}_{2}$ emissons to the atmosphere is possible since all gases would leave at $<100$ ppmv of $\mathrm{SO}_{2}$. The major uncertainty is whether lime scrubbing would be considered to have a proven ability for continuous operation at $<150$ ppmv of $\mathrm{SO}_{2}$ in the gaseous effluent.

In line with the basic EPA philosophy, incineration, which is independent of the boiler system, must employ sulfur-free fuel. 


\section{ACKNOWLEDGMENTS}

The assistance of Dr. F. E. Witmer, DOE Project Manager, in

formulating this study and expediting its initiation is appreciated. 


\section{REFERENCES}

1. Environmental Protection Agency, Standards Support and Environmental Impact Statement, Vol. I: Proposed Standards of Performance for Lurgi Coal Gasification Plants, Public Information Center, PM-215,' draft (November 1976).

2. R. Skamser, Coal Gasification Commercial Concepts Gas Cost Guidelines, C. F. Braun \& Co., Alhambro, Calif. (January 1976) [Prepared for ERDA and American Gas Association, Contract No. E (49-18)-1235].

3. Synthetic Fuels Data Handbook, Cameron Engineers, Inc., Houston, Tex.

4. Transwestern Pipeline et al., Amended Application for Certificate of Public Convenience and Necessity, F.P.C. Docket No. CP 73-211 (1975).

5. M. R. Beychok, "Sulfur Emissions Control for a Coal Gasification Plant," EPA Conference, EPA No. 2 on Environmental Aspects of Solid Fue1 Cunversion, Dec. 1S, 1975.

6. P. Crow, "Prospects seem brighter for U.S. LNG and SNG," OiZ Gas $J$. $\underline{76}(3): 23-28$ (1978).

7. Coalcon, Commercial Plant Process Evaluation Report, ERDA Clean Boiler Fuel Demonstration Plant Program, Contract No. E(49-18)-1736 (Aug. 15, 1975).

8. J. Zink Company, personal communication to J. F. Fisher, ORNL, August 1977.

9. S. Kimura et a1., Industrial Applications of Facilitated Traneport, General Electric Corporate R\&D (January 1977). 
10. S. Kimura, General Electric Corporate R\&D, "Membrane Costs," personal communication to J. M. Holmes, ORNL, Aug. 24, 1977.

11. K. A. Beuters et a1., Fifteenth Symposium on Combustion, Combustion Institute, Pittsburgh, Pa., 1974.

12. G. Skrotzki and W. Vopat, Power Station Engineering and Economy, McGraw-Hill, N.Y., (1966).

13. T. H. Carr, Electric Power Stations, 3rd ed., Chapman and Hal1, London, G.B. 1947.

14. Copeland Systems, Inc., personal communication to J. F. Fisher, 1972.

15. L. C. Hardison, Air Resources, Palatine, I11., "Econ-Abator,"* letter and company literature to J. F. Fisher, ORNL, Sept. 9, 1977.

16. R. H. Lechlet, Engelhard Industries Division S̄ystems Department, Union, N..T., "SNG Plant Tail Gas Abatement System," letter to J. F. Fisher, URNL, SepL. G, 1977.

17. Coalcon, Commercial Plant Process Evaluation Report, ERDA Clean Boiler Fuel Demonstration Plant Program Contract No. E(49-18)-1736 (July 31, 1976).

18. A. Kohl and F. Riesenfeld, Gas Purification, Gulf Yublish1ng Co., Houston, Tex., , 1974.

19. R. Egalos et a1., "Purification of Gases for Ammonia Manufacture, Removal of $\mathrm{CO}$ by Cuproammonium Carbonate Solutions," Ind. Eng. Chem. $47(5), 887$ (1955).

\footnotetext{
${ }^{*}$ Registered trademark.
} 
20. P. L. Boron, Calgon Corporation Activated Carbon Division, Pittsburgh, Pa., "Loading Capacities of Activated Carbon and BPL Carbon Technical Literature," letter to J. F. Fisher, ORNL, Aug. 15, 1977.

21. B. C. Cajander et a1., "Prediction of Equilibrium Ratios from Nonograms for Improved Accuracy," J. Chem. Data $\underline{5}$ (3), 252 (July 1963).

22. H. C. Meyers and J. M. Lenoir, "Get Your K's by Nomogram," Pet. Refiner 36(2), 167 (February 1957).

23. R. J. Gugnoni et a1., " $\mathrm{CO}_{2}-\mathrm{Ethane}$ System Predictions," Hydrocarbons Process. 52(9), 197 (September 1973).

24. F. T. Princiotta, "Advances in $\mathrm{SO}_{2}$ Stack Gas Scrubbing," Chem. Eng. Prog. 74(2), 58-64 (1978).

25. C. Grimm et a1., "The Colstrip Flue Gas Cleanup System," Chem. Eng. Prog. 74(2), 51-57 (1978). 
ORNL/TM-6229

Dist. Category UC-90d

INTERNAL DISTRIBUTION

$\begin{aligned} \text { 1. } & \text { C. R. Boston } \\ 2 . & \text { C. H. Brown } \\ 3 . & \text { H. D. Cochran, Jr. } \\ \text { 4. } & \text { K. E. Cowser } \\ \text { 5. } & \text { O. L. Culberson } \\ 6 . & \text { S. G. DeCicco } \\ \text { 7. } & \text { M. S. Edwards } \\ 8 . & \text { D. E. Ferguson } \\ 9 . & \text { J. F. Fisher } \\ 10-12 . & \text { W. R. Gambill } \\ 13 . & \text { C. W. Gehrs } \\ 14-16 . & \text { R. W. Glass } \\ 17 . & \text { J. R. Hightower, Jr. } \\ 18 . & \text { J. M. Holmes } \\ 19 . & \text { J. K. Huffstetler } \\ 20 . & \text { J. E. Jones, Jr. } \\ 21 . & \text { J. A. Klein } \\ 22-24 . & \text { L. E. McNeese } \\ 25 . & \text { J. P. Meyer } \\ 26 . & \text { B. Niemann } \\ 27 . & \text { G. R. Peterson } \\ 28 . & \text { T. W. Pickel }\end{aligned}$

1. C. R. Boston

3. H. D. Cochran, Jr.

K. E. Cowser

6. S. G. DeCicco

7. M. S. Edwards

8. D. E. Ferguson

17. J. R, Hightower, Jr.

18. J. M. Holmes

20. J. E. Jones, Jr.

21. J. A. Klein

25. J. P. Meyer

26. B. Niemann

28. T. W. Pickel
29. H. Postma

30. W. R. Reed

31. C. R. Richmond

32. M. W. Rosenthal

33. R. Salmon

34. C. D. Scott

35. M. Siman-Tov

36. S. P. N. Sing

37. D. B. Trauger

38. W. C. Ulrich

39. R. G. Wymer

40. G. R. Choppin (Consu1tant)

41. L. J. Colby, Jr. (Consultant)

42. E. L. Gaden, Jr. (Consultant)

43. L. E. Swabb (Consultant)

44. K. D. Timmerhaus (Consultant)

45. ORNL Patent Section

46. Lab Records RC

47-48. Lab Records

49-50. Central Research Library

51. Document Reference Section

EXTERNAL DIGTRIBUTION

Department of Energy, Fossil Energy, 400 First Street

Washington, D.C. 20545

52. J. D. Batchelor (Room 508)

53. E. L. Clark (Room 407)

54. N. P. Cochran (Room 501)

55. D. Garrett (Room 504)

56. H. T. Jones (Room 501)

57. T. K. Lau (Room 504)

58. G. McGur1 (Room 407)

59. J. J. Powell (Room 504)

60. H. L. Weisenfeld (Rnnm 501)

Department of Energy, Follwil Energy, 20 Maosachusells Avenue, N.W., washington, D.C. 20545

61. J. A. Belding (Room 2220)

62. C. W. DiBella (Room 4217)

63. H. Frankel (Room 4203)

64. L. M. Joseph (Room 4128)

65. L. Kindley (Rnom 4206)

66. C. W. Knudsen (Room 4217)

67. T. B. Simpson (Room 4128/RB) 
Department of Energy, Division of Environmental Control Technology, Mail Stop E-201, Washington, D.C. 20545

68. N. F. Barr

69. W. E. Mott

70. R. W. Wood

71. F. E. Witmer

Department of Energy, Division of Technology Overview, Mail Stop 7111, Federal Building, Washington, D.C. 20545

72. D. R. Monti

73. W. Wilson

74-76. R. H. Lamb (Cnnsul tant), 538 West Hunt Road, Alcoa, Tennessee 37701

77-79. L. Seglin (Consultant), Econergy Associates, 799 Broadway, New York, New York 10003

80. F. L. Culler, Electric Power Research Institute, 3412 Hillview Avenue, Palo Alto, California 94303

81. Theresa Wiley, Institute Librarian, University of Kentucky, Institute for Mining and Materials Research, 213 Bradley Hall, Lexington, Kentucky 40506

82. Robert Rabin, National Science Foundation, 1800 G. Street, NW, Washington, D.C. 20550

83. Charles B. Sedman, U.S. Environmental Protection Agency, Research Triangle Park, North Carolina 27711

84-89. DOE Pittsburgh Energy Research Center, Department of Energy Administration, Attention: Director for J. P. Barreca, 4800 Forbes Avenue, Pittsburgh, Pennsylvania 15213

90-95. The Director, Morgantnwn Energy Rescarch Center, P.0. Box 800, Morgantown, West Virginia 26506.

96. Department of Energy, Oak Ridge Operations, Research and Technical Support Division

97-407. Given distribution as shown in TID-4500 under Coal Conversion and Utilization-Liquefaction category 